\title{
Studies on the Mechanism-of-Action of Prekinamycin, a Member of the Diazoparaquinone Family of Natural Products: Evidence for both sp² Radical and Orthoquinonemethide Intermediates
}

\author{
Ken S. Feldman ${ }^{\star}$ and Kyle J. Eastman \\ 104 Chemistry Building, Department of Chemistry, The Pennsylvania State University, University \\ Park, Pennsylvania 16802 USA
}

\begin{abstract}
The putative reductive activation chemistry of the diazoparaquinone antibiotics was modeled with $\mathrm{Bu}_{3} \mathrm{Sn}-\mathrm{H}$ and prekinamycin dimethyl ether along with prekinamycin itself. Reaction in various combinations of aromatic solvents, with and without the nucleophile benzylmercaptan present, led to isolation of both radical trapping arene adducts and nucleophilic capture benzyl thioether products. Based upon these product distribution studies, the intermediacy of first, a cyclopentenyl radical, and next, an orthoquinonemethide electrophile, is postulated.
\end{abstract}

\section{Introduction}

The diazoparaquinone family of antibiotics, exemplified by its founding members kinamycin A-D (1a) - (1d), ${ }^{1}$ recently has been enlarged by the discovery of the potent anticancer marine isolates lomaiviticins A (4) and B, Figure $1 .^{2}$ In addition to these species, at least 16 other kinamycins, all varying as per the alcohol acylation pattern and/or D-ring oxidation level, and the aromatic D-ring biosynthetic precursor prekinamycin (5), define this group of natural products. ${ }^{3}$ The rarity of the diazo function in naturally occurring compounds is emphasized by the fact that only five other entries have been reported to date, as shown in Fig. $2 .{ }^{4}$ Whereas none of these species possess the diazoparaquinone function characteristic of the kinamycins and lomaiviticins, they do display antitumor and/or antibiotic activity, presumably as a consequence of a reactive $\mathrm{N}_{2}$ unit. ${ }^{4 b-f}$ However, it is the profound cytotoxic activity of the diazoparaquinone-containing compounds that has captivated the imagination of several groups, and preliminary mechanism-of-action hypotheses have been generated, Scheme 1.

Jebaratnam and coworkers (Hypothesis 1) offered the first defined proposal based on the observation that the model compound diazofluorene (10) nicks plasmid DNA upon exposure to the oxidant $\mathrm{Cu}(\mathrm{OAc})_{2} .{ }^{5}$ They suggested that similar chemistry with the kinamycins and endogenous oxidants may lead to a reactive intermediate (radical 11?) that could damage DNA via known oxygen-mediated pathways. ${ }^{6}$ Later, Dmitrienko argued for an electrophilic intermediate based upon the facile alkylation of isoprekinamycin with $\beta$-naphthol (Hypothesis 2). ${ }^{7}$ Central to this thesis is the observation that the des hydroxyl control $\mathbf{1 3}$ did not function similarly, a result which led to the proposal that internal hydrogen bonding is a key activator of 6 by virtue of rendering the $\mathrm{N}_{2}$ function more diazonium-like and hence more electrophilic when compared with the diazo-like moiety of $\mathbf{1 3}$ (note the $\mathrm{N}_{2}$ IR absorptions for $\mathbf{6} \mathrm{vs.} \mathbf{1 3}$ ). Presumably, an extension of this proposition to the diazoparaquinones would lead to the expectation that kinamycin $\mathrm{F}$ (1f), for example, would react through the diazonium-like 
resonance form 1f' with biologically relevant nucleophiles. One concerning point, however, that may cloud this interpretation of diazoparaquinone reactivity emerges upon consideration of the $\mathrm{N}_{2}$ stretching frequencies for the $\mathrm{H}$-bond capable kinamycin $\mathrm{F}(\mathbf{1 f})\left(2120 \mathrm{~cm}^{-1}\right)$ compared with the $\mathrm{H}$-bond incapable derivative kinamycin $\mathrm{J}(\mathbf{1 j})\left(2150 \mathrm{~cm}^{-1}\right) .{ }^{1 \mathrm{c}}$ The fact that the $\mathrm{H}$-bond incapable species has the higher (more diazonium-like) $\mathrm{N}_{2}$ stretch does not lend support to the Dmitrienko hypothesis, at least in so far as it applies to the diazoparaquinones.

A significant new clue regarding the biological mechanism-of-action of the diazoparaquinones might be found in He et al.'s lomaiviticin isolation/characterization studies, wherein the authors note that "An ongoing study showed that lomaiviticin A cleaved double stranded DNA under reducing conditions". 2 The role that reductive activation might play in Jebaratnam's oxidative hypothesis or in Dmitrienko's electrophilic activation proposal remains unclear, especially since neither study included diazoparaquinone-bearing species. Thus, there may be room for consideration of alternative schemes through which the apparently reductively activated diazoparaquinone-containing natural products might elicit their striking cytotoxicity.

Much earlier work in the mitomycin field has led to formulation of the paradigm that a lone pair of electrons situated adjacent to a paraquinone function is sequestered by vinylogous resonance (e.g., 14), but upon 1-electron reduction of the paraquinone, the lone pair is liberated and can participate in further chemistry, Eq. (1). ${ }^{8}$

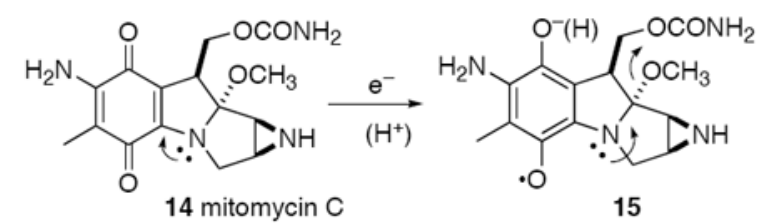

Extending this line of reasoning to the diazoparaquinones leads to a similar proposition that entails formation of the 3-electron system 17a by 1-electron reduction of $\mathbf{1 6}$, Scheme 2 . By reapportioning the 3 -electron array as shown in the equivalent resonance form $\mathbf{1 7 b}$, a role for the diazo unit is revealed. Specifically, $\beta$-elimination of $\mathrm{N}_{2}$ gas from the naphthalenolate moiety within $17 \mathrm{c}$ can provide a new reactive intermediate, the $\mathrm{sp}^{2}$ radical species 18 . The facility of this transform may in large measure depend on the trade-off between the energetic penalty associated with the pyramidalization of $\mathrm{C}(11)$ required for alignment of the $\pi$ cloud with $\sigma^{*} \mathrm{C}-\mathrm{N}$ and the energetic gain resulting from nitrogen gas expulsion. It is not possible at this juncture to predict whether thermodynamics should trump kinetics for this process or vice versa, but if the former scenario pertains, then the net result is the transfer of the input electron into a carbon-bound radical at $\mathrm{C}(11)$. One significant consequence of this elimination reaction becomes apparent when considering the fate of the $\mathrm{C}(11)$ radical; it must, out of mechanistic necessity, switch its occupancy from a $\pi$-orbital to an $\mathrm{sp}^{2}$ orbital. Thus, the diazoparaquinones may have evolved to incorporate a transduction mechanism that converts biologically accessible 1-electron (radical?) reductants into potentially much more reactive $\mathrm{sp}^{2}$ carbon radicals.

The biological chemistry of $\mathrm{sp}^{2}$ radicals with DNA in general, $6 \mathrm{~b}$ and cyclopentenyl $\mathrm{sp}^{2}$ radicals in particular, 9 has been well documented, as exemplified in Eq. (2). ${ }^{10}$ Given the dimeric structure of the lomaiviticins, the claim of double strand nicking may be rationalized by invoking two DNA damaging events that each extend from the chemistry of a radical of the type 18 generated independently from each half. 


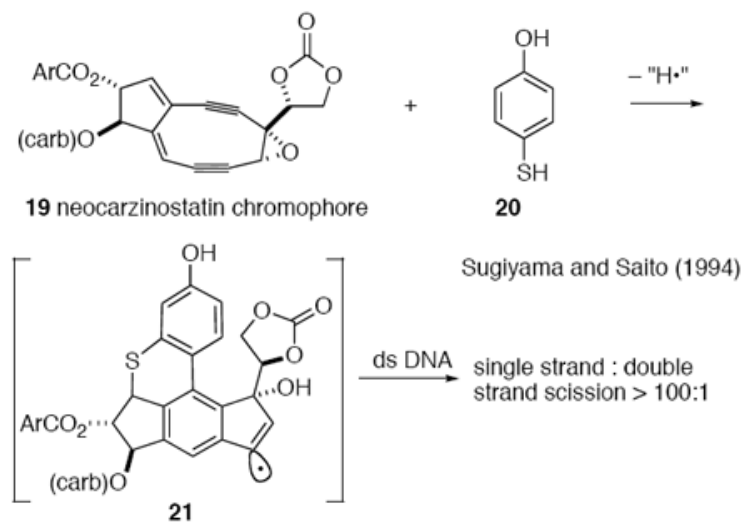

In contrast to the neocarzinostatin chromophore chemistry 21+DNA-H, diazoparaquinone/ DNA chemistry has the potential to go beyond hydrogen abstraction/radical reactions (i.e., $\mathrm{DNA} \bullet+\mathrm{O}_{2}$ ) in its capacity to inflict chemical damage on DNA. For example, rebound radical addition of DNA • with $\mathbf{2 2}$ might afford a covalent adduct 23. An even more intriguing line of conjecture emerges upon consideration of the structural consequences of hydrogen abstraction by $\mathbf{1 8}$ to furnish the closed shell species 22; a hydroxymethylacylfulvene subunit, which is the key electrophilic pharmacophore implicated in the potent cytotoxicity of the eponymous family of promising anticancer agents (cf. 26), ${ }^{11}$ is generated. By analogy with the chemistry of $\mathbf{2 6}$, base alkylation by the electrophilic orthoquinonemethide $\mathbf{2 2}$, as exemplified by the speculative depiction of a conjugate addition of guanosine $\mathrm{N}(7)$ with $\mathrm{C}(11),{ }^{8 \mathrm{~b}}$ can provide an entirely independent and orthogonal avenue to introduce damage into DNA, 24 $\rightarrow \mathbf{2 5}$. N(7)-Alkylated guanosines are reported to undergo spontaneous depurination to furnish an abasic site. ${ }^{12}$ The relative contributions (if any) of cyclopentenyl radical 18 and/or orthoquinonemethide 22 to the biological activity of the diazoparaquinones remains a matter of speculation, but it is possible that this rare diazoparaquinone chemical functionality has emerged through evolutionary pressure to act as an inducible (by 1-electron reduction) source of these two potentially lethal reactive intermediates. Interestingly, the isolation of the shunt metabolite seongomycin (27) from the fermentation broth of a prekinamycin-producing organism can be interpreted in terms of the transformation $\mathbf{1 6} \rightarrow \mathbf{2 2}$ (with an aromatic prekinamycin D ring), and then trapping of $\mathbf{2 2}$ by $\mathrm{N}$-acetyl cysteine and reoxidation of the derived hydroquinone. ${ }^{13}$

The exploration of these mechanistic hypotheses was undertaken using prekinamycin (5) and derived species with $\mathrm{Bu}_{3} \mathrm{SnH}$ as a model 1-electron reductant. These abiological conditions certainly limit the breadth of the conclusions that can be drawn, but they also arguably can serve to reveal the intrinsic chemistry of the diazoparaquinone function under reducing conditions regardless of the environment. Extrapolation from these studies to the biological chemistry of the lomaiviticins or kinamycins can be no more rigorous than argument-byanalogy, and a stronger connection will have to await the results of further experimentation in a relevant biological milieu. In the investigation to follow, evidence is presented that speaks to the core transforms of the mechanistic proposition offered in Schemes 2 and 3; formation of an $\mathrm{sp}^{2}$ radical $\mathbf{1 8}$ from diazoparaquinones under 1-electron reductive conditions, and its subsequent conversion to a competent electrophile $\mathbf{2 2}$ by H-atom abstraction.

\section{Results and Discussion}

Prekinamycin (5) was chosen as the starting point for these mechanistic studies, as it had the dual benefits of (1) embodying the key structural features of this family (diazoparaquinone, hydrogen bond donors adjacent to the carbonyls) while at the same time (2) being readily 
accessible through synthesis. ${ }^{14}$ The biological activity of prekinamycin apparently has not been reported, and so it is not possible to assess the validity of using these aromatic D-ring species as stand-ins for the oxidized D ring kinamycins that do display potent cytotoxicity. In addition to the natural product itself, both the diacetate $\mathbf{2 8}$ and the dimethyl ether $\mathbf{2 9}$ were prepared also in an attempt to both test the necessity of activation via $\mathrm{H}$-bonding to the carbonyl as per Dmitrienko's postulate, and to provide probe molecules whose solubility properties might make experimentation easier, Scheme 4. Both the dimethyl ether $\mathbf{2 9}$ and the diacetate 28 were prepared by Hauser as part of his prekinamycin synthesis work. ${ }^{14}$ The initial experiments were designed to explore the simple question of whether the formal addition of $\underline{\mathrm{H}}_{2}\left(\right.$ as $\left.\mathrm{Bu}_{3} \mathrm{Sn}-\underline{\mathrm{H}}, \underline{\mathrm{H}}^{+}\right)$would lead to an isolable orthoquinonemethide 30. Cognizance of a report by $\mathrm{Kim}^{15}$ that the diazoketone 31 reacted with the $\mathrm{H} \bullet$ - equivalent reagent $\mathrm{Bu}_{3} \mathrm{Sn}-\mathrm{H}$ to furnish the formal $\mathrm{Sn}-\mathrm{H}$ addition product $\mathbf{3 2}$ stimulated thinking along similar lines with prekinamycin, $\mathbf{5} \rightarrow \mathbf{3 0}$ a. However, concerns about the stability/reactivity of a putative addition product 30a could not be dismissed readily, especially in light of the disclosure that the related natural products monofulvenones A and B (33a) and (33b), respectively, decomposed within minutes upon addition of dilute acid. ${ }^{16}$ Presumably, the protonated version of $\mathbf{3 3 a} / \mathbf{3 3 b}$ can express its orthoquinonemethide reactivity to the detriment of isolation attempts. The question, then, is, will the aromatic $\mathrm{D}$ ring of the desired kinamycin adduct 30a mitigate its reactivity enough, compared with the potentially activating $C(4)$ carbonyl of $\mathbf{3 3 a} \mathbf{3} \mathbf{3 3 b}$, so that it could be isolated?

The answer, unfortunately, is no. Treatment of 5 with $\mathrm{Bu}_{3} \mathrm{Sn}-\mathrm{H} / \mathrm{AIBN}$ in $\mathrm{C}_{6} \mathrm{D}_{6}$ at $80{ }^{\circ} \mathrm{C}$ did not lead to detection of any product, even as a minor component, that possessed the orthoquinonemethide unit of 30/30a, Scheme 4 . In fact, a single compound was formed in good yield, but initial examination of its ${ }^{1} \mathrm{H}$ NMR spectrum generated more puzzlement than illumination. All of the peaks of the A-B-C-D ring platform were identifiable and present, but the identity of the attachment at C(11) was not apparent. In what was to be the first of several surprises with the reductive chemistry of $\mathbf{5}$, further spectroscopic analysis revealed the unequivocal presence of solvent deuterobenzene attached to this reactive center, $\mathbf{3 4}$. Given the rather modest reactivity of benzene, this result implied that the reductive conditions with $\mathbf{5}$ were generating some type of highly reactive intermediate, and at this juncture none of the obvious candidates - carbene, carbocation (or electrophilic orthoquinonemethide equivalent), or radical - could be ruled out. Control experiments with substrate $\mathbf{2 9}$ as indicated in Table 1 did provide some guidance in that they (a) demand the presence of all radical generating ingredients, and (b) exclude the possibility that either a purely thermally or a photochemically generated species is involved.

The crude product mixtures were purified via $\mathrm{SiO}_{2}$ chromatography to furnish pure $\mathbf{3 4 a}$ from $\mathbf{5}, 35$ from 28, and 36 from 29. Despite much effort with modified conditions of reaction, workup or purification, no tin-bearing species (cf. 34a with $\mathrm{R}_{1}=\mathrm{Bu}_{3} \mathrm{Sn}$, compare 32) could be isolated. Attempts to prepare a more stable version of $\mathbf{3 4 a}\left(\mathrm{R}_{1}=\mathrm{SnPh}_{3}\right.$ or $\left.\mathrm{Si}(\mathrm{TMS})_{3}\right)$ with $\mathrm{Ph}_{3} \mathrm{Sn}-\mathrm{H}$ or $\mathrm{TMS}_{3} \mathrm{Si}-\mathrm{H}$ did not provide any benefit in this regard. Both the diacetate 28 and the dimethyl ether $\mathbf{2 9}$ performed similarly under these reductive tin conditions, leading to the respective phenyl adducts in good yields. The higher yield of adduct $\mathbf{3 6}$ with the dimethyl ether 29 can be attributed to ease of chromatographic purification of the product compared to 34a or 35, both of which streaked on $\mathrm{SiO}_{2}$. All of the subsequent chemistry was conducted with 29 for this reason. The ability to H-bond to the carbonyl (5 vs. 29) apparently has no significant bearing of the facility of this chemistry.

Identifying the reactive intermediate, generated upon reduction of $\mathbf{2 9}$, which participates in C$\mathrm{C}$ bond formation with benzene became the focus of the next series of experiments. A priori, a C(11) carbene seemed the least likely candidate given the type of products formed and the results of the control experiments, and so distinguishing between the remaining two 
possibilities, a $\mathrm{C}(11)$ radical or a $\mathrm{C}(11)$ electrophile (orthoquinonemethide $\approx$ secondary carbocation), was of paramount concern. The use of aryl substituent effects in the context of a Hammet-type study provided one avenue to probe this question. Towards this end, the prekinamycin dimethyl ether substrate $\mathbf{2 9}$ was exposed to the usual mixture of $\mathrm{Bu}_{3} \mathrm{SnH}$ and AIBN in a variety of equimolar mixtures of benzene and other substituted aromatic solvents, Table 2. Absolute chemical yields of the benzene adduct $\mathbf{3 6}$ and the substituted arene analogues 39 were recorded, as were ortho:meta:para ratios (or other substituent ratios, as appropriate). Standard Hammet (para) substituent constants $\sigma$ were used for this analysis, which necessitated normalizing the raw data. ${ }^{17}$

The undeniable dogleg exposed by graphing the data from entries $a$ - $d$ of Table 2 against $\sigma$ (see Figure 3) provides little support for a hypothesis that depends upon a $\mathrm{C}(11)$ cationic intermediate for $\mathrm{C}-\mathrm{C}$ bond formation to the arene. That any non-hydrogen substituent on the arene accelerates adduct formation is reinforced by the dual substituent entries $e$ - $g$ of Table 2, where a rough additivity in rates is seen for 1,3-dimethyl, 1-3-dimethoxy, and 1,3-

dicyanobenzene compared to the corresponding monsubstituted species. The facts that (1) 1,3dicyanobenzene is the most reactive arene solvent examined, and (2) this electron-deficient arene is closely followed in relative reactivity by the electron rich 1,3-dimethoxybenzene, argues perhaps the most persuasively against adduct formation via an electrophilic orthoquinonemethide intermediate. However, these observations, in and of themselves, do not permit the rigorous exclusion of this species from further consideration if it were perhaps just a minor player with the more electron-rich arenes (vide infra).

And so, by process of elimination, the mechanistic picture for conversion of $\mathbf{2 9}$ into 36/39, or by extension the similar conversion of $\mathbf{5}$ into $\mathbf{3 4 a}$, can be refined substantially to include a prominent role for direct $\mathrm{sp}^{2}$ radical addition to the arene solvent, ${ }^{18}$ Scheme 5 . Thus, the data presented in Table 2 are consistent with a sequence whereby $\mathrm{sp}^{2}$ radical $\mathbf{4 2}$, generated by formal 1-electron reduction of $\mathbf{2 9}$ with loss of $\mathrm{N}_{2}$, adds directly to the arene ring of the solvent to furnish a transient cyclohexadienyl radical-containing adduct $\mathbf{4 3}$. Despite the fact that the transformation is run under globally reducing conditions, the apparent oxidation of this radical by AIBN itself to reformulate the aryl ring of product $\mathbf{4 4}$ is not unexpected, as per the work of Beckwith et al. ${ }^{19}$ Workup via $\mathrm{SiO}_{2}$ chromatography then provides the detected product(s) 36/39.

If the orthoquinonemethide $\mathbf{4 5}$ is formed from $\mathbf{4 2}$ by hydrogen abstraction from $\mathrm{Bu}_{3} \mathrm{Sn}-\mathrm{H}$, it is unclear at this point whether this electrophile plays any productive (even if only minor) role in adduct formation, at least with the electron rich arene solvents. The overall chemical yields of the arene adducts ranged from $52-80 \%$, leaving as an open question the fate of the remainder of the starting material. The diversion of $\mathbf{4 2}$ to the orthoquinonemethide $\mathbf{4 5}$ may account for some of the consumed $\mathbf{2 9}$, as this species apparently does not participate in direct adduct formation with the electron deficient arenes (vide infra). With electron rich arenes, however, some minor involvement of Friedel-Crafts-type alkylation with $\mathbf{4 5}$ may occur to give the reduced hydroquinone adduct $\mathbf{4 7}$, which can suffer air-induced oxidation to intercept 44 en route to the observed product 39 . If this electrophile mechanistic channel were expressed, the oxidation/hydrolysis sequence that forms $\mathbf{3 9}$ from $\mathbf{4 7}$ might just as reasonably be reversed (i.e., hydrolysis and then oxidation).

The conclusion regarding the prominence of radical addition chemistry over orthoquinonemethide chemistry only pertains to reactions with an aromatic solvent nucleophile. Extrapolating to a biological milieu, where much more potent nucleophilic partners for putative orthoquinonemethide $\mathbf{4 5}$ are present, would not seem warranted. Studies to be discussed shortly do provide some insight into this question about the role of $\mathbf{4 5}$ under such circumstances (vide infra). Further support for the radical-as-key-intermediate hypothesis 
in these arene additions can be garnered from two observations: (1) similar relative rates and similar ortho:meta:para ratios for thiazole-derived radical $\mathbf{4 0}$ addition to substituted arenes have been recorded by Dou (see Table 2), ${ }^{20}$ and (2) small and variable amounts of the C(11) dimer 49 were isolated from many of the runs, Scheme 6. The formation of $\mathbf{4 9}$ is difficult to explain without invoking the intermediacy of radical 42, either by direct dimerization or through participation of the derived but undetected orthoquinonemethide, $\mathbf{4 2}+\mathbf{4 5} \rightarrow \mathbf{4 8}$, or $\mathbf{4 5}+\mathbf{4 5} \rightarrow \mathbf{5 0} \rightarrow \mathbf{4 9}$.

A few more attempts to trap radical 42 with other radical-reactive reagents were explored, Eq. 3. Standard reaction of $29 / \mathrm{Bu}_{3} \mathrm{SnH} / \mathrm{AIBN}$ in the presence of $\mathrm{Ph}_{2} \mathrm{Se}_{2}$ led to formation of the $\mathrm{C}$ (11) selenium adduct $\mathbf{5 1}$ along with the benzene addition product $\mathbf{3 6}$. Attempts to perform the tin hydride-mediated reduction of $\mathbf{2 9}$ in non-aromatic solvents were uniformly unrewarding, as reaction in either THF, 1,4-dioxane, $\mathrm{CCl}_{4}, \mathrm{CH}_{3} \mathrm{CN}$, EtOH, or $\mathrm{Cl}_{3} \mathrm{CH}$ returned only unreacted starting material. These observations, taken together, may point to a defined role for the aromatic solvent in either promoting the formation of, or possibly stabilizing, the $\mathrm{sp}^{2}$ radical by $\pi$-complexation.

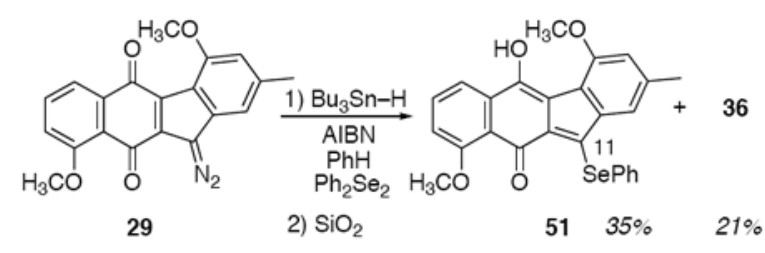

So, if some orthoquinonemethide $\mathbf{4 5}$ is formed from $\mathbf{4 2}$, what is its fate? This question was probed through two different types of experiments featuring either (1) variation of the $\mathrm{Bu}_{3} \mathrm{SnH} /$ substrate ratio, or, independently, (2) examining the product distribution when nucleophiles that are better than arene rings are present. The partitioning of radical 42 into either the arene adduct 43 or the putative orthoquinonemethide 45 should be responsive to the tin hydride concentration if the mechanistic model detailed in Scheme 5 is applicable. In the case of an electron deficient solvent, any orthoquinonemethide $\mathbf{4 5}$ so formed would not lead to adduct formation, and so the overall yield of adducts 36/39, which can only derive from 42 , should decrease as $\left[\mathrm{Bu}_{3} \mathrm{SnH}\right]$ increases. This hypothesis was tested by exposing a 1:1 molar mixture of $\mathrm{PhH}$ and $\mathrm{PhCN}$ to $29 / \mathrm{AIBN} /$ (varying) $\mathrm{Bu}_{3} \mathrm{SnH}$ at $80^{\circ} \mathrm{C}$, Figure 4 . The data obtained from these studies support this interpretation, as the overall yield of arene adducts decrease linearly with increasing $\left[\mathrm{Bu}_{3} \mathrm{SnH}\right]$ over the range $1-12$ equivalents of the tin reagent. Verification of the expectation that adduct formation derives only from radical $\mathbf{4 2}$ and not orthoquinonemethide $\mathbf{4 5}$ for these non-electron rich arenes can be seen by examining the 39c/ 36 ratio as a function of $\left[\mathrm{Bu}_{3} \mathrm{SnH}\right]$; this ratio remains constant within experimental error, indicating no change in mechanism as tin hydride concentration increases.

This situation changes noticeably when an electron rich aromatic solvent, 1,3dimethoxybenzene, is used in place of $\mathrm{PhCN}$, Figure 5. For these experiments, the overall yield of arene adducts $\mathbf{3 9 f}+\mathbf{3 6}$ decreases roughly monotonically at lower tin hydride concentration, but then this trend reverses at the highest $\left[\mathrm{Bu}_{3} \mathrm{SnH}\right]$ examined, where the yield of total arene adducts actually increases. Could the orthoquinonemethide $\mathbf{4 5}$ now be playing a role in adduct formation $(\mathbf{4 5} \rightarrow \mathbf{4 6} \rightarrow \mathbf{4 7} \rightarrow \mathbf{3 9 f}$, cf. Scheme 5$)$ with this more nucleophilic solvent? Evidence in support of this hypothesis can be found by examining the ratio of arene adducts $\mathbf{3 9 f} / \mathbf{3 6}$ as a function of tin hydride concentration; unlike the electron deficient $\mathrm{PhCN}$ trials, the ratio favoring the electron rich adduct $39 \mathrm{f}$ again increases at high $\left[\mathrm{Bu}_{3} \mathrm{SnH}\right]$. These observations are entirely consistent with incursion of the orthoquinonemethide reaction channel to some extent 
in (electron rich) arene adduct formation. Thus, it appears that both reactive intermediates, the $\mathrm{sp}^{2}$ radical $\mathbf{4 2}$ and the orthoquinonemethide $\mathbf{4 5}$, are generated sequentially upon formal 1electron reduction of diazoparaquinone $\mathbf{2 9}$, and both species can be trapped if the appropriate complementary reaction partners are present.

The last series of experiments were designed to probe the question of whether the orthoquinonemethide $\mathbf{4 5}$ might be coaxed into playing a bigger role in product formation if a reagent much more nucleophilic than a methoxyaromatic solvent were included in the reaction mixture. In fact, these trials begin to speak to the question of relevance to the chemistry of diazoparaquinones in a biological setting, where nucleophiles such as thiols and amines (cf. Scheme 3) might participate in adduct formation. Inclusion of benzylmercaptan in the reaction solution provided the means to test these ideas. Treatment of a solution of diazoparaquinone 29, either 1.1 or 12 equivalents of $\mathrm{Bu}_{3} \mathrm{SnH}$, and 10 equivalents of $\mathrm{PhCH}_{2} \mathrm{SH}$ in benzene solvent at reflux with 1.1 equivalents of AIBN in benzene led to results which encouraged the point of view that the orthoquinonemethide $\mathbf{4 5}$ may, in fact, be a major player in the chemistry of diazoparaquinones under 1-electron reducing conditions as long as suitable nucleophile partners are present. Thus, the products of direct radical $\mathbf{4 2}$ addition to benzene, $\mathbf{3 6}$ and $\mathbf{5 3}$, are formed in a combined yield of $37 \%$ with 1.1 equivalents of $\mathrm{Bu}_{3} \mathrm{SnH}$, and in a combined $33 \%$ yield with 12 equivalents of $\mathrm{Bu}_{3} \mathrm{SnH}$. That $\mathbf{5 2}$ precedes $\mathbf{5 3}$ is suggested by the independent synthesis of $\mathbf{5 3}$ from $\mathbf{3 6}$ and $\mathrm{PhCH}_{2} \mathrm{SH}$. So, if approximately one third of the starting diazoparaquinone can be accounted for by the direct radical addition pathway under these experimental conditions, where is the other $2 / 3$ going? It was gratifying to see that about half of the starting material was converted into the $\mathrm{C}(11)$ benzylmercaptan adduct $\mathbf{5 4}$, a species that retains the $\mathrm{C}(11)$ hydrogen as well. The hydroquinone $\mathbf{5 4}$ was moderately sensitive to quinone formation via air oxidation, but careful handling under a $\mathrm{N}_{2}$ atmosphere reduced this unwanted side reaction to almost undetectable levels. The most concise explanation for the formation of this benzylmercaptan adduct involves reaction through the orthoquinonemethide electrophile 45, where now the much greater nucleophilicity of the thiol, compared with aromatic solvents, provides a ready trap for this reactive entity. No evidence for the dimerization product $\mathbf{4 9}$ was garnered in these thiol-containing runs. In a critical control experiment, refluxing a solution of diazoparaquinone $\mathbf{2 9}$ with 100 equivalents of benzylmercaptan in benzene led to absolutely no evidence for chemical reaction, and $\mathbf{2 9}$ could be recovered unchanged from this test. The incorporation of radical generating (reducing) reagents appears to be an inescapable requirement for reaction. The lack of direct nucleophilic addition between the thiol and the diazo function of $\mathbf{2 9}$ does not lend support to the nucleophilic activation mechanism of Dmitrienko (Scheme 1), although the claimed H-bond activation within 6 is absent in 29. In order to probe this point further, the H-bond capable species prekinamycin (5) itself was subjected to the same control - exposure to 100 equivalents of $\mathrm{PhCH}_{2} \mathrm{SH}$ in refluxing benzene - to the same end; no evidence for chemical reaction was detected and $\mathbf{5}$ could be recovered unchanged.

The isolation of a reaction product $\mathbf{5 4}$ that still retained a presumably tin hydride-donated hydrogen at $\mathrm{C}(11)$ leads to the obvious labeling experiment with $\mathrm{Bu}_{3} \mathrm{Sn}-\mathrm{D}$, Scheme 8 . Not so obvious was the result when diazoparaquinone $\mathbf{2 9}$ was combined with 12 equivalents of the tin deuteride and 10 equivalents of $\mathrm{PhCH}_{2} \mathrm{SH}$ in refluxing benzene; the expected $\mathrm{C}(11)$ benzylthiolated hydroquinone product $\mathbf{5 6}$ was isolated in good yield, but with only $27 \%$ deuterium incorporation at C(11) ( ${ }^{1} \mathrm{H}$ NMR analysis). The unexpectedly high proton count in 56 was partially explained by rerunning the labeling experiment with $\mathrm{PhCH}_{2} \mathrm{SD}$ as the source of deuterium. In this instance, the hydroquinone $\mathbf{5 6}$ was formed with $46 \%$ deuterium incorporation at $\mathrm{C}(11)$. As controls, heating a mixture of either $\mathrm{Bu}_{3} \mathrm{Sn}-\mathrm{D} / \mathrm{PhCH}_{2} \mathrm{SH}$ or, independently, $\mathrm{Bu}_{3} \mathrm{Sn}-\mathrm{H} / \mathrm{PhCH}_{2} \mathrm{SD}$ in benzene with AIBN present did not lead to any deuterium crossover. Finally, it was comforting to note that when both $\mathrm{Bu}_{3} \mathrm{Sn}-\mathrm{D}$ and $\mathrm{PhCH}_{2} \mathrm{SD}$ were used simultaneously, the deuterium count in the product $56(76 \%)$ matched 
the sum of the deuterium incorporations of the two single-deuterium-source experiments. The origin of the remaining $\sim 25 \%$ of protium in the double-deuterium-source experiment remains a mystery, although $\mathrm{PhCH}_{2} \mathrm{SH}$ may be a likely candidate. No further labeling studies were pursued to probe this point.

\section{Conclusions}

In summary, the results described herein provide a comprehensive picture of the chemistry that unfolds when a diazoparaquinone-containing species, prekinamycin dimethyl ether (29), is treated with the formal 1-electron reductant $\mathrm{Bu}_{3} \mathrm{Sn}-\mathrm{H} / \mathrm{AIBN}$. Evidence in support of a mechanistic sequence involving first, a C(11) $\mathrm{sp}^{2}$ radical, and then an electrophilic orthoquinonemethide, has been obtained. The radical intermediate is a competent partner for additions with either electron deficient or electron rich arenes, whereas the subsequent orthoquinone species will react with both electron rich arenes and an alkyl thiol. The relevance of this chemistry to the larger question of kinamycin/lomaiviticin mechanism-of-action remains to be established, but at the very least, these results speak to the intrinsic chemistry available to diazoparaquinone-containing species under reducing conditions, and they hint at plausible reaction chemistry within a biological milieu.

\section{Experimental}

\section{General Procedure 1. Phenylation of Prekinamycin and Derivatives}

AIBN (1.1 equiv) in benzene $(0.06 \mathrm{M})$ was added via syringe pump addition over a period of $1 \mathrm{~h}$ to a stirring solution of diazoparaquinones $\mathbf{5 , 2 8}$ or $\mathbf{2 9}$ ( 1 equiv) and $\mathrm{Bu}_{3} \mathrm{SnH}$ (1.1 equiv) in benzene $(0.06 \mathrm{M})$ at $80^{\circ} \mathrm{C}$. When the addition was complete, the reaction solution was allowed to cool to room temperature. After reaching room temperature the reaction mixture was concentrated in vacuo. The resulting residue was purified by flash chromatography on $\mathrm{SiO}_{2}$ using the specified eluent.

\section{General Procedure 2. Aromatic Solvent Competition Experiments}

AIBN (1.1 equiv) in an equimolar solution of benzene and the indicated aromatic solvent ( 0.06 M) was added via syringe pump addition over a period of $1 \mathrm{~h}$ to a stirring solution of diazoparaquinone 29 ( 1 equiv) and $\mathrm{Bu}_{3} \mathrm{SnH}$ ( 1.1 equiv) also in an equimolar solution of benzene and the indicated aromatic solvent $(0.06 \mathrm{M})$ at $80^{\circ} \mathrm{C}$. When the addition was complete, the reaction solution was allowed to cool to room temperature. After reaching room temperature the reaction mixture was diluted with $\mathrm{CH}_{2} \mathrm{Cl}_{2}$, poured onto a $\mathrm{SiO}_{2}$ column, and purified by eluting with $\mathrm{CH}_{2} \mathrm{Cl}_{2}$ with an increasing percentage of either EtOAc or acetone from $0 \%$ to 10 $\%$. Purification furnished the clean benzene trapped product $\mathbf{3 6}$ and in most cases a mixture of ortho, meta, and para or the 2,4- and 2,6-regioisomers of the given substituted aromatic trapped product 39a-g. Relative rates were quantified by product mass comparison of the substituted aromatic adducts 39 vs. the benzene addition product 36. Isolation of analytical samples of pure ortho, meta or para (or the 2,4- or 2,6-regioisomers) from chromatography permitted ${ }^{1} \mathrm{H}$ NMR identification. In cases where isomer separation was not achieved, the ratios were determined by inspection of ${ }^{1} \mathrm{H}$ NMR spectra of the mixtures.

\section{General Procedure 3. Aromatic Solvent Competition Experiments with Varying Equivalents of Tin}

General Procedure 2 was used, varying only in the equivalents of $\mathrm{Bu}_{3} \mathrm{SnH}$ used as indicated in Figures 4 and 5. 


\section{4,5,9-Trihydroxy-2-methyl-11-phenyl-benzo[b]fluoren-10-one (34a)}

Following General Procedure 1, prekinamycin (5) $(18 \mathrm{mg}, 0.057 \mathrm{mmol})$ was converted into benzo[b]fluorenone 34a (12.3 mg, 59\%): $\mathrm{mp} 260{ }^{\circ} \mathrm{C}$ (dec); IR (neat): $3409,1585 \mathrm{~cm}^{-1}$; Presumably, due to the partial free radical nature of $\mathbf{3 4 a}$ analogous to kinobscurinone, ${ }^{21} \mathbf{3 4 a}$ appears to be "NMR silent", exhibiting neither a ${ }^{1} \mathrm{H}$ - nor a ${ }^{13} \mathrm{C}$ NMR signature; $\mathrm{ESI} \mathrm{m} / z$ relative intensity 391( $\left.\mathrm{MNa}^{+} 100\right)$; TOFHRMS (+ESI) Calcd for $\mathrm{C}_{24} \mathrm{H}_{16} \mathrm{O}_{4} \mathrm{Na}$ : 391.0946, Found 391.0947.

\section{Acetic acid 9-Acetoxy-11-diazo-2-methyl-5,10-dioxo-10,11-dihydro-5H-benzo[b]fluoren-4-yl ester (28)}

Pyridine ( $3.6 \mathrm{~mL}, 28 \mathrm{mmol})$ and $\mathrm{Ac}_{2} \mathrm{O}(3.6 \mathrm{~mL}, 44 \mathrm{mmol})$ were sequentially added to a mixture of $5(150 \mathrm{mg}, 0.471 \mathrm{mmol})$ and DMAP $(6.0 \mathrm{mg}, 0.05 \mathrm{mmol})$ in $\mathrm{CH}_{2} \mathrm{Cl}_{2}(15.0 \mathrm{~mL})$ at room temperature. The dark purple mixture was stirred at room temperature for 2 days, turning to a dark red color. At this time, the reaction solution was diluted with saturated aqueous $\mathrm{NaHCO}_{3}(50 \mathrm{~mL})$ and $\mathrm{CH}_{2} \mathrm{Cl}_{2}(30 \mathrm{~mL})$. The layers were separated and the aqueous layer was extracted with $\mathrm{CH}_{2} \mathrm{Cl}_{2}(3 \times 10 \mathrm{~mL})$. The combined organic layers were washed with water and brine, dried over $\mathrm{Na}_{2} \mathrm{SO}_{4}$, filtered and concentrated. The resulting dark red solid was purified by flash chromatography on silica gel eluting with $\mathrm{CH}_{2} \mathrm{Cl}_{2} / \mathrm{EtOAc}(99: 1)$ to yield the di-acetate (28) as a red solid (156 mg, 85\%): $\mathrm{mp} 205^{\circ} \mathrm{C}$ (dec); IR (neat): 3365, 2924, 2102, 1766 $\mathrm{cm}^{-1} ;{ }^{1} \mathrm{H}$ NMR $\left(300 \mathrm{MHz}, \mathrm{CDCl}_{3}\right) \delta 8.17(\mathrm{~d}, J=7.8 \mathrm{~Hz}, 1 \mathrm{H}), 7.72(\mathrm{t}, J=7.9 \mathrm{~Hz}, 1 \mathrm{H}), 7.30$ $(\mathrm{d}, J=7.9 \mathrm{~Hz}, 1 \mathrm{H}), 7.20(\mathrm{~s}, 1 \mathrm{H}), 6.89(\mathrm{~s}, 1 \mathrm{H}), 2.57(\mathrm{~s}, 3 \mathrm{H}), 2.47(\mathrm{~s}, 3 \mathrm{H}), 2.46(\mathrm{~s}, 3 \mathrm{H}) ;{ }^{13} \mathrm{C}$ NMR $\left(75 \mathrm{MHz}, \mathrm{CDCl}_{3}\right) \delta 180.0,177.6,171.0,170.0,150.0,147.6,139.7,137.7,137.2,136.7$, 136.4, 135.2, 129.0, 126.4, 126.0, 124.3, 122.3, 121.9, 116.9, 22.1, 21.9, 21.6; ESI m/z relative intensity $425\left(\mathrm{MNa}^{+} 72\right)$; TOFHRMS (+ESI) Calcd for $\mathrm{C}_{22} \mathrm{H}_{15} \mathrm{~N}_{2} \mathrm{O}_{6} \mathrm{Na}$ : 425.0750, Found 425.0738 .

\section{Acetic Acid 9-Acetoxy-5-hydroxy-2-methyl-10-oxo-11-phenyl-10H-benzo[b]fluoren-4-yl Ester (35)}

Following General Procedure 1, diazoparaquinone 28 (17.5 mg, $0.044 \mathrm{mmol})$ was converted into benzo[b]fluorenone $\mathbf{3 5}$ (9.8 mg, 50\%): $\mathrm{mp} 200{ }^{\circ} \mathrm{C}$ (dec); IR (neat): 3330, 1789, 1766 $\mathrm{cm}^{-1} ;{ }^{1} \mathrm{H} \mathrm{NMR}\left(400 \mathrm{MHz}, \mathrm{CDCl}_{3}\right) \delta 9.39(\mathrm{~s}, 1 \mathrm{H}), 7.88(\mathrm{~d}, J=7.9 \mathrm{~Hz}, 1 \mathrm{H}), 7.56(\mathrm{t}, J=8.0 \mathrm{~Hz}$, $2 \mathrm{H}), 7.55(\mathrm{~d}, J=7.7 \mathrm{~Hz}, 1 \mathrm{H}), 7.41-7.50(\mathrm{~m}, 3 \mathrm{H}), 7.06(\mathrm{~d}, J=8.0 \mathrm{~Hz}, 1 \mathrm{H}), 7.06(\mathrm{~s}, 1 \mathrm{H}), 7.05$ (s, 1H), $2.51(\mathrm{~s}, 3 \mathrm{H}), 2.36(\mathrm{~s}, 3 \mathrm{H}), 2.32(\mathrm{~s}, 3 \mathrm{H}),{ }^{13} \mathrm{C} \mathrm{NMR}\left(100 \mathrm{MHz}, \mathrm{CDCl}_{3}\right) \delta 180.2,170.2$, $166.9,151.3,149.9,147.9,144.4,143.3,138.5,135.7,133.9,133.8,129.7,128.8,128.7,128.2$, $126.5,125.4,123.3,123.2,123.0,122.6,114.6,21.7,21.6,21.3 ; \mathrm{ESI} \mathrm{m} / z$ relative intensity 475 $\left(\mathrm{MNa}^{+} 100\right)$; TOFHRMS (+ESI) Calcd for $\mathrm{C}_{28} \mathrm{H}_{20} \mathrm{O}_{6} \mathrm{Na}$ : 475.1158, Found 475.1142.

\section{5-Hydroxy-4,9-dimethoxy-2-methyl-11-phenyl-benzo[b]fluoren-10-one (36)}

Following General Procedure 1, diazoquinone $29(10.5 \mathrm{mg}, 0.032 \mathrm{mmol})$ was converted into benzo[b]fluorenone $\mathbf{3 6}$ (10.0 mg, 79\%): $\mathrm{mp} 220^{\circ} \mathrm{C}$ (dec); IR (neat): $3181,1633 \mathrm{~cm}^{-1} ;{ }^{1} \mathrm{H} \mathrm{NMR}$ $\left(400 \mathrm{MHz}, \mathrm{CDCl}_{3}\right) \delta 10.76(\mathrm{~s}, 1 \mathrm{H}), 7.58(\mathrm{~d}, J=7.6 \mathrm{~Hz}, 1 \mathrm{H}), 7.56(\mathrm{~d}, J=6.8 \mathrm{~Hz}, 2 \mathrm{H}), 7.48(\mathrm{t}$, $J=8.2 \mathrm{~Hz}, 1 \mathrm{H}), 7.45(\mathrm{t}, J=7.1 \mathrm{~Hz}, 2 \mathrm{H}), 7.39(\mathrm{~d}, J=7.2 \mathrm{~Hz}, 1 \mathrm{H}), 7.00(\mathrm{~d}, J=8.4 \mathrm{~Hz}, 1 \mathrm{H})$, $6.81(\mathrm{~s}, 1 \mathrm{H}), 6.67(\mathrm{~s}, 1 \mathrm{H}), 4.09$ (s, 3H), $3.90(\mathrm{~s}, 3 \mathrm{H}), 2.32(\mathrm{~s}, 3 \mathrm{H}) ;{ }^{13} \mathrm{C} \mathrm{NMR}(100 \mathrm{MHz}$, $\left.\mathrm{CDCl}_{3}\right) \delta 182.0,161.8,151.9,151.1,146.6,144.3,138.7,136.9,135.0,134.6,130.0,129.4$, $128.4,128.2,128.1,120.0,119.2,117.8,115.0,114.9,115.2,56.9,56.6,22.2 ; \mathrm{ESI} \mathrm{m} / z$ relative intensity $497\left(\mathrm{MH}^{+}\right.$50); TOFHRMS (+ESI) Calcd for $\mathrm{C}_{26} \mathrm{H}_{21} \mathrm{O}_{4}$ : 397.1440, Found 397.1443.

\section{Acetic Acid 4,5-Diacetoxy-2-methyl-10-oxo-11-phenyl-10H-benzo[b]fluoren-9-yl Ester (37)}

From 34a-Pyridine $(0.26 \mathrm{~mL}, 3.1 \mathrm{mmol})$ and $\mathrm{Ac}_{2} \mathrm{O}(0.31 \mathrm{~mL}, 3.1 \mathrm{mmol})$ were added sequentially to a mixture of $\mathbf{3 4 a}(11.0 \mathrm{mg}, 0.031 \mathrm{mmol})$ and DMAP $(1.0 \mathrm{mg}, 0.008 \mathrm{mmol})$ in $\mathrm{CH}_{2} \mathrm{Cl}_{2}(1.0 \mathrm{~mL})$ at room temperature. The dark purple mixture was stirred at room temperature 
for $30 \mathrm{~min}$, turning to a dark red/orange color. At this time, the reaction solution was diluted with saturated aqueous $\mathrm{NaHCO}_{3}(10 \mathrm{~mL})$ and $\mathrm{CH}_{2} \mathrm{Cl}_{2}(10 \mathrm{~mL})$. The layers were separated and the aqueous layer was extracted with $\mathrm{CH}_{2} \mathrm{Cl}_{2}(3 \times 10 \mathrm{~mL})$. The combined organic layers were washed with water and brine, dried over $\mathrm{Na}_{2} \mathrm{SO}_{4}$, filtered and concentrated. The resulting dark red solid was purified by flash chromatography on silica gel $\left(\mathrm{CH}_{2} \mathrm{Cl}_{2}\right)$ to yield the triacetate 37 as a bright orange solid ( $8.1 \mathrm{mg}, 52 \%)$.

From 35-Pyridine $(0.070 \mathrm{~mL}, 0.90 \mathrm{mmol})$ and $\mathrm{Ac}_{2} \mathrm{O}(0.85 \mathrm{~mL}, 0.90 \mathrm{mmol})$ were sequentially added to a mixture of $\mathbf{3 5}(4.0 \mathrm{mg}, 0.90 \mathrm{mmol})$ and DMAP $(1.0 \mathrm{mg}, 0.008 \mathrm{mmol})$ in $\mathrm{CH}_{2} \mathrm{Cl}_{2}(1.0 \mathrm{~mL})$ at room temperature. The dark red mixture was stirred at room temperature for $30 \mathrm{~min}$, changing to a dark red/orange color. At this time, the reaction solution was diluted with saturated aqueous $\mathrm{NaHCO}_{3}(10 \mathrm{~mL})$ and $\mathrm{CH}_{2} \mathrm{Cl}_{2}(10 \mathrm{~mL})$. The layers were separated and the aqueous layer was extracted with $\mathrm{CH}_{2} \mathrm{Cl}_{2}(3 \times 10 \mathrm{~mL})$. The combined organic layers were washed with water and brine, dried over $\mathrm{Na}_{2} \mathrm{SO}_{4}$, filtered and concentrated. The resulting dark red solid was purified by flash chromatography on silica gel $\left(\mathrm{CH}_{2} \mathrm{Cl}_{2}\right)$. The triacetate 37 was obtained as a orange solid (4.4 mg, 99\%): $\mathrm{mp} 195{ }^{\circ} \mathrm{C}$ (dec); IR (neat): $1769,1635 \mathrm{~cm}^{-1} ;{ }^{1} \mathrm{H}$ NMR $\left(500 \mathrm{MHz}, \mathrm{CDCl}_{3}\right) \delta 7.59(\mathrm{~d}, J=7.8 \mathrm{~Hz}, 1 \mathrm{H}), 7.58(\mathrm{~d}, J=7.3 \mathrm{~Hz}, 1 \mathrm{H}), 7.47-7.52(\mathrm{~m}$, $4 \mathrm{H}), 7.39(\mathrm{~d}, J=8.3 \mathrm{~Hz}, 1 \mathrm{H}), 7.01(\mathrm{~d}, J=7.7 \mathrm{~Hz}, 1 \mathrm{H}), 6.99(\mathrm{~s}, 1 \mathrm{H}), 6.80(\mathrm{~s}, 1 \mathrm{H}), 2.53(\mathrm{~s}, 3 \mathrm{H})$, $2.43(\mathrm{~s}, 3 \mathrm{H}), 2.31(\mathrm{~s}, 6 \mathrm{H}) ;{ }^{13} \mathrm{C} \mathrm{NMR}\left(125 \mathrm{MHz}, \mathrm{CDCl}_{3}\right) \delta 179.4,169.6,168.7,167.6,154.6$, 151.4, 145.9, 145.2, 142.0, 141.1, 136.5, 133.8, 132.8, 129.4, 129.3, 129.3, 128.9, 128.0, 125.9, $125.3,124.8,124.2,123.7,121.8,21.3,21.2,21.1,20.9 ; \mathrm{ESI} \mathrm{m} / z$ relative intensity 517

$\left(\mathrm{MNa}^{+} 100\right)$; TOFHRMS (+ESI) Calcd for $\mathrm{C}_{30} \mathrm{H}_{22} \mathrm{O}_{7} \mathrm{Na}$ : 517.1263, Found 517.1245.

\section{4,5,9-Trimethoxy-2-methyl-11-phenyl-benzo[b]fluoren-10-one (38)}

From 34a-Methyl iodide $(0.042 \mathrm{~mL}, 0.68 \mathrm{mmol})$ was added to a mixture of 34a $(25.0 \mathrm{mg}$, $0.068 \mathrm{mmol})$ and $\mathrm{K}_{2} \mathrm{CO}_{3}(93.0 \mathrm{mg}, 0.068 \mathrm{mmol})$ in DMF $(2.0 \mathrm{~mL})$ at room temperature. The dark purple mixture was stirred at room temperature for $12 \mathrm{~h}$, turning to a dark red color. The reaction solution was then diluted with saturated aqueous $\mathrm{NH}_{4} \mathrm{Cl}(10 \mathrm{~mL})$ and $\mathrm{Et}_{2} \mathrm{O}(10 \mathrm{~mL})$. The layers were separated and the aqueous layer was extracted with $\mathrm{Et}_{2} \mathrm{O}(3 \times 10 \mathrm{~mL})$. The combined organic layers were washed with water and brine, dried over $\mathrm{Na}_{2} \mathrm{SO}_{4}$, filtered and concentrated. The resulting light red solid was purified by flash chromatography on silica gel $\left(\mathrm{CH}_{2} \mathrm{Cl}_{2}\right)$. The tri methyl ether 38 was obtained as a bright red solid $(11.5 \mathrm{mg}, 41 \%)$.

From 36-Methyl iodide $(0.031 \mathrm{~mL}, 0.50 \mathrm{mmol})$ was added to a mixture of $\mathbf{3 6}(20.0 \mathrm{mg}$, $0.050 \mathrm{mmol})$ and $\mathrm{K}_{2} \mathrm{CO}_{3}(69.0 \mathrm{mg}, 0.050 \mathrm{mmol})$ in $\mathrm{DMF}(1.0 \mathrm{~mL})$ at room temperature. The dark red mixture was stirred at room temperature for $12 \mathrm{~h}$, turning to a light red color. The reaction was then diluted with saturated aqueous $\mathrm{NH}_{4} \mathrm{Cl}(10 \mathrm{~mL})$ and $\mathrm{Et}_{2} \mathrm{O}(10 \mathrm{~mL})$. The layers were separated and the aqueous layer was extracted with $\mathrm{Et}_{2} \mathrm{O}(3 \times 10 \mathrm{~mL})$. The combined organic layers were washed with water and brine, dried over $\mathrm{Na}_{2} \mathrm{SO}_{4}$, filtered and concentrated. The resulting light red solid was purified by flash chromatography on silica gel $\left(\mathrm{CH}_{2} \mathrm{Cl}_{2}\right)$. The tri methyl ether 38 was obtained as a bright red solid $(12.0 \mathrm{mg}, 59 \%)$ : $\mathrm{mp} 210{ }^{\circ} \mathrm{C}(\mathrm{dec})$; IR (neat): $1643 \mathrm{~cm}^{-1} ;{ }^{1} \mathrm{H}$ NMR $\left(300 \mathrm{MHz}, \mathrm{CDCl}_{3}\right) \delta$ 7.50-7.60 (m, 2H), 7.40-7.50 (m, 5H), 6.96 $(\mathrm{dd}, J=6.7,2.7 \mathrm{~Hz}, 1 \mathrm{H}), 6.76(\mathrm{~s}, 1 \mathrm{H}), 6.59(\mathrm{~s}, 1 \mathrm{H}), 4.02(\mathrm{~s}, 3 \mathrm{H}), 3.96(\mathrm{~s}, 3 \mathrm{H}), 3.89$ (s, 3H), $2.32(\mathrm{~s}, 3 \mathrm{H}) ;{ }^{13} \mathrm{C}$ NMR $\left(75 \mathrm{MHz}, \mathrm{CDCl}_{3}\right) \delta 181.5,161.6,155.2,153.0,151.7,145.3,140.3$, 138.7, 134.3, 134.2, 130.1, 129.2, 128.3, 127.8, 126.8, 121.4, 118.3, 118.2, 117.4, 113.9, 113.6, 63.9, 56.1, 55.9, 21.7; ESI m/z relative intensity $411\left(\mathrm{MH}^{+} 100\right)$; TOFHRMS (+ESI) Calcd for $\mathrm{C}_{27} \mathrm{H}_{22} \mathrm{O}_{4}$ : 411.1596, Found 411.1596 .

\section{5-Hydroxy-4,9-dimethoxy-2-methyl-11-p-tolyl-benzo[b]fluoren-10-one (39a)}

Following General Procedure 2, diazoparaquinone $29(20.0 \mathrm{mg}, 0.060 \mathrm{mmol})$ was converted into a 2:1 mixture of benzo[b]fluorenone 39a (ortho:meta:para $=62: 23: 15)(7.4 \mathrm{mg}, 30 \%)$ and benzo[b]fluorenone $\mathbf{3 6}(3.6 \mathrm{mg}, 15 \%)$. Note that the $2.2: 1$ ratio of $\mathbf{3 9 a}$ to $\mathbf{3 6}$ that is reported in 
Table 2 reflects the average of 5 independent runs. (ortho:meta:para mixture) IR (neat): 3190 , $1633 \mathrm{~cm}^{-1}$; ortho isomer: ${ }^{1} \mathrm{H}$ NMR $\left(500 \mathrm{MHz} \mathrm{CDCl}_{3}\right) \delta 10.64(\mathrm{~s}, 1 \mathrm{H}), 7.60(\mathrm{~d}, J=7.9 \mathrm{~Hz}$, $1 \mathrm{H}), 7.50(\mathrm{t}, J=8.1 \mathrm{~Hz}, 1 \mathrm{H}), 7.22-7.36(\mathrm{~m}, 3 \mathrm{H}), 7.19(\mathrm{~d}, J=7.3 \mathrm{~Hz}, 1 \mathrm{H}), 7.01(\mathrm{~d}, J=8.3 \mathrm{~Hz}$, $1 \mathrm{H}), 6.69(\mathrm{~s}, 1 \mathrm{H}), 6.54(\mathrm{~s}, 1 \mathrm{H}), 4.11(\mathrm{~s}, 3 \mathrm{H}), 3.89(\mathrm{~s}, 3 \mathrm{H}), 2.31(\mathrm{~s}, 3 \mathrm{H}), 2.16(\mathrm{~s}, 3 \mathrm{H})$; (ortho:meta:para mixture) ${ }^{1} \mathrm{H} \mathrm{NMR}\left(500 \mathrm{MHz}^{\mathrm{C}} \mathrm{CDCl}_{3}\right) \delta 10.76(\mathrm{~s}, 0.4 \mathrm{H}$, meta, para), 10.68 $(\mathrm{s}, 0.6 \mathrm{H}, o) 7.60(\mathrm{~d}, J=7.7 \mathrm{~Hz}, 0.5 \mathrm{H}), 7.59(\mathrm{~d}, J=7.4 \mathrm{~Hz}, 0.5 \mathrm{H}), 7.47-7.51(\mathrm{~m}, 1 \mathrm{H}), 7.33-7.36$ (m, 1H), 7.22-7.30 (m, 2H), $7.19(\mathrm{~d}, J=6.8 \mathrm{~Hz}, 1 \mathrm{H}), 7.01(\mathrm{~d}, J=8.3 \mathrm{~Hz}, 1 \mathrm{H}), 6.85(\mathrm{~s}, 0.25 \mathrm{H})$, $6.79(\mathrm{~s}, 0.25 \mathrm{H}), 6.69(\mathrm{~s}, 1 \mathrm{H}), 6.54(\mathrm{~s}, .5 \mathrm{H}), 4.11(\mathrm{~s}, 1.8 \mathrm{H}, o), 4.10(\mathrm{~s}, 1.2 \mathrm{H}$, meta, para $), 3.90$ (s, 1.2H, meta, para) $3.89(\mathrm{~s}, 1.8 \mathrm{H}, o), 2.35$ (s, 1.8H, meta, para), 2.31 (s, 1.8H,o), 2.16 (s, 3H); (ortho:meta:para mixture) ${ }^{13} \mathrm{C} \mathrm{NMR}\left(125 \mathrm{MHz}, \mathrm{CDCl}_{3}\right) \delta 181.5,161.3,151.5,150.6$, $145.9,144.2,138.5,136.7,136.5,135.1,134.0,129.9,129.5,128.5,127.6,126.6,125.4,121.3$, $119.4,118.9,118.6,117.4,114.6,114.4,111.1,56.53,56.5,56.5,21.8,21.7,19.9 ; \mathrm{ESI} \mathrm{m} / z$ relative intensity $411\left(\mathrm{MH}^{+} 30\right)$; TOFHRMS (+ESI) Calcd for $\mathrm{C}_{27} \mathrm{H}_{22} \mathrm{O}_{4}$ : 411.1596, Found 411.1611 .

\section{1-(4-Chlorophenyl)-5-hydroxy-4,9-dimethoxy-2-methyl-benzo[b]fluoren-10-one (39b)}

Following General Procedure 2, diazoparaquinone 29 (20.0 mg, $0.060 \mathrm{mmol}$ ) was converted into a 1.8:1 mixture of benzo[b]fluorenone 39b (ortho:meta:para $=48: 32: 20)(9.5 \mathrm{mg}, 37 \%$ ) and benzo[b]fluorenone $36(5.0 \mathrm{mg}, 21 \%)$. Note that the $1.5: 1$ ratio of $\mathbf{3 9 b}$ to $\mathbf{3 6}$ that is reported in Table 2 reflects the average of 5 independent runs. 39b isomers were separated via preparative TLC (20\% EtOAc in benzene). ortho isomer: $\mathrm{mp} 280{ }^{\circ} \mathrm{C}$ (dec); IR (neat): 3178 , $1630 \mathrm{~cm}^{-1} ;{ }^{1} \mathrm{H}$ NMR $\left(500 \mathrm{MHz}, \mathrm{CDCl}_{3}\right) \delta 10.76(\mathrm{~s}, 1 \mathrm{H}), 7.60(\mathrm{~d}, J=7.8 \mathrm{~Hz}, 1 \mathrm{H}), 7.50(\mathrm{~m}$, 2H), $7.33(\mathrm{~m}, 3 \mathrm{H}), 7.02(\mathrm{~d}, J=8.2 \mathrm{~Hz}, 1 \mathrm{H}), 6.69(\mathrm{~s}, 1 \mathrm{H}), 6.58(\mathrm{~s}, 1 \mathrm{H}), 4.11(\mathrm{~s}, 3 \mathrm{H}), 3.90(\mathrm{~s}$, $3 \mathrm{H}), 2.33$ (s, 3H). meta isomer: $\mathrm{mp} 260{ }^{\circ} \mathrm{C}$ (dec); IR (neat): $3378,1630 \mathrm{~cm}^{-1}$; ${ }^{1} \mathrm{H}$ NMR $(500$ $\left.\mathrm{MHz}, \mathrm{CDCl}_{3}\right) \delta 10.82(\mathrm{~s}, 1 \mathrm{H}), 7.60(\mathrm{~d}, J=8.2 \mathrm{~Hz}, 1 \mathrm{H}), 7.51(\mathrm{~m}, 2 \mathrm{H}), 7.44(\mathrm{~d}, J=6.8 \mathrm{~Hz}, 1 \mathrm{H})$, $7.38(\mathrm{t}, J=7.8 \mathrm{~Hz}, 1 \mathrm{H}), 7.37(\mathrm{~s}, 1 \mathrm{H}), 7.30(\mathrm{~d}, J=8.3 \mathrm{~Hz}, 1 \mathrm{H}), 6.75(\mathrm{~s}, 1 \mathrm{H}), 6.71(\mathrm{~s}, 1 \mathrm{H}), 4.12$ $(\mathrm{s}, 3 \mathrm{H}), 3.91(\mathrm{~s}, 3 \mathrm{H}), 2.36(\mathrm{~s}, 3 \mathrm{H})$. para isomer: $\mathrm{mp} 240^{\circ} \mathrm{C}(\mathrm{dec})$; IR (neat): 3166,1631 $\mathrm{cm}^{-1} ;{ }^{1} \mathrm{H} \mathrm{NMR}\left(500 \mathrm{MHz} \mathrm{CDCl}_{3}\right) \delta 10.81(\mathrm{~s}, 1 \mathrm{H}), 7.60(\mathrm{~d}, J=8.4 \mathrm{~Hz}, 1 \mathrm{H}), 7.52(\mathrm{~d}, J=8.6$ $\mathrm{Hz}, 2 \mathrm{H}), 7.50$ (t, $J=8.2 \mathrm{~Hz}, 1 \mathrm{H}), 7.42(\mathrm{~d}, 8.6 \mathrm{~Hz}, 2 \mathrm{H}), 7.30(\mathrm{~d}, J=8.4 \mathrm{~Hz}, 1 \mathrm{H}), 6.79(\mathrm{~s}, 1 \mathrm{H})$, $6.71(\mathrm{~s}, 1 \mathrm{H}), 4.12(\mathrm{~s}, 3 \mathrm{H}), 3.92(\mathrm{~s}, 3 \mathrm{H}), 2.35(\mathrm{~s}, 3 \mathrm{H})$; (ortho:meta:para mixture) ${ }^{13} \mathrm{C} \mathrm{NMR}(125$ $\left.\mathrm{MHz}, \mathrm{CDCl}_{3}\right) \delta 181.6,181.5,181.3,161.3,151.5,151.4,151.3,151.1,144.5,143.5,143.3$, $142.3,138.5,136.6,136.5,136.4,134.1,133.8,133.7,133.2,131.1,130.7,130.3,129.5,129.2$, $129.1,128.9,128.3,128.1,127.9,126.5,121.1,119.6,119.5,119.3,118.5,118.4,118.3,117.5$, 114.7, 114.4, 114.2, 111.2, 111.1, 56.6, 56.5, 56.2, 56.1, 21.8, 21.7; ESI m/z relative intensity $431\left(\mathrm{MH}^{+} 100\right)$; TOFHRMS (+ESI) Calcd for $\mathrm{C}_{26} \mathrm{H}_{20} \mathrm{O}_{4} \mathrm{Cl}$ : 431.1050 , Found 431.1060 .

\section{4-(5-Hydroxy-4,9-dimethoxy-2-methyl-10-oxo-10H-benzo[b]fluoren-11-yl)benzonitrile (39c)}

Following General Procedure 2, diazoparaquinone 29 (20.0 mg, $0.060 \mathrm{mmol})$ was converted into a 2.2:1 mixture of benzo[b]fluorenone 39c (ortho:meta:para $=43: 25: 32)(13.0 \mathrm{mg}, 51 \%$ ) and benzo[b]fluorenone $36(5.6 \mathrm{mg}, 23 \%)$. Note that the $2.1: 1$ ratio of $39 \mathrm{c}$ to 36 that is reported in Table 2 reflects the average of 5 independent runs. 39c isomers were separated via preparative TLC (20\% EtOAc in benzene). ortho isomer: $\mathrm{mp} 265^{\circ} \mathrm{C}$ (dec); IR (neat): 3394, 2232, $1631 \mathrm{~cm}^{-1} ;{ }^{1} \mathrm{H}$ NMR $\left(500 \mathrm{MHz}, \mathrm{CDCl}_{3}\right) \delta 10.87(\mathrm{~s}, 1 \mathrm{H}), 7.77(\mathrm{~d}, J=7.6 \mathrm{~Hz}, 1 \mathrm{H}), 7.66$ $(\mathrm{t}, J=7.7 \mathrm{~Hz}, 1 \mathrm{H}), 7.61(\mathrm{~d}, J=7.9 \mathrm{~Hz}, 1 \mathrm{H}), 7.52(\mathrm{t}, J=8.2 \mathrm{~Hz}, 1 \mathrm{H}), 7.49(\mathrm{~d}, J=7.8 \mathrm{~Hz}, 1 \mathrm{H})$, $7.46(\mathrm{t}, J=7.7 \mathrm{~Hz}, 1 \mathrm{H}), 7.03(\mathrm{~d}, J=8.2 \mathrm{~Hz}, 1 \mathrm{H}), 6.71(\mathrm{~s}, 1 \mathrm{H}), 6.58(\mathrm{~s}, 1 \mathrm{H}), 4.13(\mathrm{~s}, 3 \mathrm{H}), 3.92$ (s, 3H), 2.34 (s, 3H). meta isomer: $\mathrm{mp} 265{ }^{\circ} \mathrm{C}(\mathrm{dec})$; IR (neat): $3412,2216,1633 \mathrm{~cm}^{-1} ;{ }^{1} \mathrm{H}$ NMR $\left(500 \mathrm{MHz}, \mathrm{CDCl}_{3}\right) \delta 10.88(\mathrm{~s}, 1 \mathrm{H}), 7.82(\mathrm{~d}, J=8.0 \mathrm{~Hz}, 1 \mathrm{H}), 7.81(\mathrm{~s}, 1 \mathrm{H}), 7.67(\mathrm{~d}, J=$ $7.7 \mathrm{~Hz}, 1 \mathrm{H}), 7.61(\mathrm{~d}, J=7.8 \mathrm{~Hz}, 1 \mathrm{H}), 7.54(\mathrm{t}, J=8.0 \mathrm{~Hz}, 1 \mathrm{H}) 7.47$ (t, $J=8.1 \mathrm{~Hz}, 1 \mathrm{H}), 7.04(\mathrm{~d}$, $J=7.7 \mathrm{~Hz}, 1 \mathrm{H}), 6.72(\mathrm{~s}, 1 \mathrm{H}), 6.70(\mathrm{~s}, 1 \mathrm{H}), 4.13(\mathrm{~s}, 3 \mathrm{H}), 3.93(\mathrm{~s}, 3 \mathrm{H}), 2.37(\mathrm{~s}, 3 \mathrm{H})$. para isomer: mp $265^{\circ} \mathrm{C}$ (dec); IR (neat): 3412, 2223, $1631 \mathrm{~cm}^{-1} ;{ }^{1} \mathrm{H} \mathrm{NMR}\left(500 \mathrm{MHz}, \mathrm{CDCl}_{3}\right) \delta 10.92$ (s, $1 \mathrm{H}), 7.73(\mathrm{~d}, J=8.4 \mathrm{~Hz}, 2 \mathrm{H}), 7.66(\mathrm{~d}, J=8.5 \mathrm{~Hz}, 2 \mathrm{H}), 7.61(\mathrm{~d}, J=7.8 \mathrm{~Hz}, 1 \mathrm{H}), 7.52(\mathrm{t}, J=$ $8.2 \mathrm{~Hz}, 1 \mathrm{H}), 7.04(\mathrm{~d}, J=8.3 \mathrm{~Hz}, 1 \mathrm{H}), 6.72(\mathrm{~s}, 1 \mathrm{H}), 6.71(\mathrm{~s}, 1 \mathrm{H}), 4.13$ (s, 3H), 3.92 (s, 3H), 2.36 
(s, 3H); (ortho:meta:para mixture) ${ }^{13} \mathrm{C}$ NMR $\left(125 \mathrm{MHz}, \mathrm{CDCl}_{3}\right) \delta 181.7,181.6,181.4,161.5$, $161.4,152.4,152.1,151.6,151.5,143.1,143.0,142.9,139.9,139.6,138.7,138.6,138.5,136.4$, $136.3,136.2,134.4,133.0,132.9,132.3,131.7,131.5,130.8,130.4,130.0,129.7,128.8,127.9$, 121.0, 119.5, 118.3, 118.1, 118.0, 117.9, 117.8, 115.2, 114.4, 114.3, 114.2, 113.1, 112.1, 111.4, $111.3,111.3,56.6,56.5,56.3,56.3,56.2,21.8 ; \mathrm{ESI} \mathrm{m} / z$ relative intensity $444\left(\mathrm{MNa}^{+} 100\right)$; TOFHRMS (+ESI) Calcd for $\mathrm{C}_{27} \mathrm{H}_{19} \mathrm{NO}_{4} \mathrm{Na}$ : 444.1212, Found 444.1215.

\section{5-Hydroxy-4,9-dimethoxy-11-(4-methoxyphenyl)-2-methyl-benzo[b]fluoren-10-one (39d)}

Following General Procedure 2, diazoparaquinone 29 (20.0 mg, $0.060 \mathrm{mmol})$ was converted into a 3.2:1 mixture of benzo[b]fluorenone 39d (ortho:meta:para $=76: 16: 12)(14.5 \mathrm{mg}, 57 \%$ ) and benzo[b]fluorenone $\mathbf{3 6}(4.3 \mathrm{mg}, 18 \%)$. Note that the $3.1: 1$ ratio of $\mathbf{3 9 d}$ to 36 that is reported in Table 2 reflects the average of 5 independent runs. Ortho isomer: $\mathrm{mp} 210^{\circ} \mathrm{C}(\mathrm{dec})$; IR (neat): $3182,1632 \mathrm{~cm}^{-1} ;{ }^{1} \mathrm{H}$ NMR $\left(500 \mathrm{MHz}, \mathrm{CDCl}_{3}\right) \delta 10.70(\mathrm{~s}, 1 \mathrm{H}), 7.58,(\mathrm{~d}, J=7.9 \mathrm{~Hz}, 1 \mathrm{H}), 7.48$ (t, $J=8.1 \mathrm{~Hz}, 1 \mathrm{H}), 7.36$ (t, $J=7.6 \mathrm{~Hz}, 1 \mathrm{H}), 7.34(\mathrm{~d}, J=7.7 \mathrm{~Hz}, 1 \mathrm{H}), 7.03(\mathrm{t}, J=7.5 \mathrm{~Hz}, 1 \mathrm{H})$, $7.01(\mathrm{~d}, J=8.2 \mathrm{~Hz}, 1 \mathrm{H}), 7.0(\mathrm{~d}, J=8.3 \mathrm{~Hz}, 1 \mathrm{H}), 6.66(\mathrm{~s}, 1 \mathrm{H}), 6.65(\mathrm{~s}, 1 \mathrm{H}), 4.10(\mathrm{~s}, 3 \mathrm{H}), 3.89$ (s, 3H), 3.73 (s, 3H), $2.32(\mathrm{~s}, 3 \mathrm{H}) ;{ }^{13} \mathrm{C}$ NMR $\left(125 \mathrm{MHz}, \mathrm{CDCl}_{3}\right) \delta 181.3,161.2,157.4,151.4$, 150.4, 144.0, 142.8, 138.1, 136.5, 133.8, 130.7, 130.0, 129.2, 124.3, 121.6, 120.4, 119.4, 118.7, 117.3, 114.7, 114.6, 111.3, 110.9, 56.5, 56.1, 55.7, 21.8. meta:para isomer: IR (neat): 3178 , 2216, $1622 \mathrm{~cm}^{-1} ;{ }^{1} \mathrm{H}$ NMR $\left(500 \mathrm{MHz}, \mathrm{CDCl}_{3}\right) \delta 10.78(\mathrm{~s}, 0.43 \mathrm{H}, p), 10.76(\mathrm{~s}, 0.57 \mathrm{H}, m), 7.59$ $(\mathrm{d}, J=7.3 \mathrm{~Hz}, 1 \mathrm{H}), 7.58(\mathrm{~d}, J=8.4 \mathrm{~Hz}, 1 \mathrm{H}), 7.49(\mathrm{t}, J=8.0 \mathrm{~Hz}, 1 \mathrm{H}), 7.37(\mathrm{t}, J=8.0 \mathrm{~Hz}, 1 \mathrm{H})$, $7.14(\mathrm{~d}, J=7.6 \mathrm{~Hz}, 0.5 \mathrm{H}), 6.98-7.06(\mathrm{~m}, 2 \mathrm{H}), 6.93(\mathrm{~d}, J=8.6 \mathrm{~Hz}, 0.5 \mathrm{H}), 6.88(\mathrm{~s}, 0.5 \mathrm{H}), 6.82$ $(\mathrm{s}, 0.5 \mathrm{H}), 6.69(\mathrm{~s}, 1 \mathrm{H}), 4.10(\mathrm{~s}, 3 \mathrm{H}), 3.91(\mathrm{~s}, 3 \mathrm{H}), 3.88(\mathrm{~s}, 1.5 \mathrm{H}), 3.88(\mathrm{~s}, 1.5 \mathrm{H}), 2.35(\mathrm{~s}, 1.5 \mathrm{H})$, 2.34 (s, $1.5 \mathrm{H}$ ); IR (neat): $3412,2223,1631 \mathrm{~cm}-1 ;{ }^{13} \mathrm{C} \mathrm{NMR}\left(125 \mathrm{MHz}, \mathrm{CDCl}_{3}\right) \delta 181.6,181.3$, 161.4, 161.2, 159.6, 159.2, 157.4, 151.4, 150.8, 150.4, 150.2, 149.4, 146.2, 145.8, 144.0, 142.8, 138.6, 138.2, 136.5, 136.4, 136.2, 136.1, 134.0, 133.8, 133.7, 131.2, 130.7, 130.0, 129.2, 128.9, 128.7, 128.3, 126.6, 124.3, 122.1, 122.0, 121.7, 121.6, 120.4, 119.8, 119.4, 118.9, 118.8, 118.7, $117.4,117.3,114.8,114.7,114.6,114.4,113.7,113.6,113.2,111.3,111.1,110.9,110.5,56.5$, $56.4,56.1,56.0,55.7,55.3,55.2,21.8,21.7 ; \mathrm{ESI} \mathrm{m} / z$ relative intensity $449\left(\mathrm{MNa}^{+} 85\right)$; TOFHRMS (+ESI) Calcd for $\mathrm{C}_{27} \mathrm{H}_{22} \mathrm{O}_{5} \mathrm{Na}$ : 449.1365, Found 449.1346.

\section{1-(3,5-Dimethylphenyl)-5-hydroxy-4,9-dimethoxy-2-methyl-benzo[b]fluoren-10-one (39e)}

Following General Procedure 2, diazoparaquinone 29 (20.0 $\mathrm{mg}, 0.060 \mathrm{mmol})$ was converted into a 3.1:1 mixture of benzo[b]fluorenone 39e $(2: 4: 5=50: 50: 0)(11.5 \mathrm{mg}, 44 \%)$ and benzo [b]fluorenone $\mathbf{3 6}$ (3.4 mg, 14\%). Note that the 4.0:1 ratio of 39e to $\mathbf{3 6}$ that is reported in Table 2 reflects the average of 5 independent runs. 39e isomers were separated via preparative TLC (1\% EtOAc in $\mathrm{CH}_{2} \mathrm{Cl}_{2}$ ). 2,4-dimethyl isomer: $\mathrm{mp} 220^{\circ} \mathrm{C}$ (dec); IR (neat): 3195,1633 $\mathrm{cm}^{-1} ;{ }_{1}^{1} \mathrm{H}$ NMR $\left(500 \mathrm{MHz}, \mathrm{CDCl}_{3}\right) \delta 10.67(\mathrm{~s}, 1 \mathrm{H}), 7.59(\mathrm{~d}, J=7.3 \mathrm{~Hz}, 1 \mathrm{H}), 7.49(\mathrm{t}, J=8.0$ $\mathrm{Hz}, 1 \mathrm{H}), 7.12(\mathrm{~s}, 1 \mathrm{H}), 7.09$ (d, $J=7.7 \mathrm{~Hz}, 1 \mathrm{H}), 7.05(\mathrm{~d}, J=7.7 \mathrm{~Hz}, 1 \mathrm{H}), 7.00(\mathrm{~d}, J=8.2 \mathrm{~Hz}$, $1 \mathrm{H}), 6.68(\mathrm{~s}, 1 \mathrm{H}), 6.58(\mathrm{~s}, 1 \mathrm{H}), 4.11(\mathrm{~s}, 3 \mathrm{H}), 3.89(\mathrm{~s}, 3 \mathrm{H}), 2.37(\mathrm{~s}, 3 \mathrm{H}), 2.30(\mathrm{~s}, 3 \mathrm{H}), 2.13(\mathrm{~s}$, $3 \mathrm{H}) ;{ }^{13} \mathrm{C} \mathrm{NMR}\left(125 \mathrm{MHz}, \mathrm{CDCl}_{3}\right) \delta 181.5,161.3,151.4,150.4,146.1,144.3,138.4,137.1$, 136.5, 136.5, 133.9, 131.9, 130.8, 129.9, 128.4, 126.1, 121.4, 119.4, 118.6, 117.3, 114.5, 114.4, $111.1,56.5,56.1,21.7,21.3,19.8$; 2,6-dimethyl isomer: $\mathrm{mp} 250{ }^{\circ} \mathrm{C}(\mathrm{dec})$; IR (neat): 3194 , $1633 \mathrm{~cm}^{-1} ;{ }^{1} \mathrm{H}$ NMR $\left(500 \mathrm{MHz}, \mathrm{CDCl}_{3}\right) \delta 10.64(\mathrm{~s}, 1 \mathrm{H}), 7.60(\mathrm{~d}, J=7.5 \mathrm{~Hz}, 1 \mathrm{H}), 7.49(\mathrm{t}, J=$ $7.8 \mathrm{~Hz}, 1 \mathrm{H}), 7.18(\mathrm{t}, J=8.1 \mathrm{~Hz}, 1 \mathrm{H}), 7.10(\mathrm{~d}, J=7.6 \mathrm{~Hz}, 2 \mathrm{H}), 7.01(\mathrm{~d}, \mathrm{~J}=8.1 \mathrm{~Hz}, 1 \mathrm{H}), 6.69$ $(\mathrm{s}, 1 \mathrm{H}), 6.45(\mathrm{~s}, 1 \mathrm{H}), 4.12(\mathrm{~s}, 3 \mathrm{H}), 3.89$ (s, 3H), 2.30 (s, 3H), 2.04 (s, 6H); ${ }^{13} \mathrm{C}$ NMR $(125 \mathrm{MHz}$, $\left.\mathrm{CDCl}_{3}\right) \delta 181.5,161.3,151.5,150.3,145.9,143.3,138.6,136.6,135.9,134.8,134.0,130.8$, 130.0, 127.1, 127.0, 121.1, 119.5, 118.0, 117.3, 114.5, 111.2, 56.4, 56.1, $20.720 .1 ; \mathrm{ESI} \mathrm{m} / z$ relative intensity $425\left(\mathrm{MH}^{+} 50\right)$; TOFHRMS (+ESI) Calcd for $\mathrm{C}_{28} \mathrm{H}_{25} \mathrm{O}_{4}: 425.1753$, Found 425.1740 . 
11-(3,5-Dimethoxyphenyl)-5-hydroxy-4,9-dimethoxy-2-methyl-benzo[b]fluoren-10-one (39f)

Following General Procedure 2, diazoparaquinone 29 (20.0 mg, $0.060 \mathrm{mmol})$ was converted into a 4.2:1 mixture of benzo[b]fluorenone 39f $(2,4: 2,6 ; 3,5=31: 69: 0)(16.2 \mathrm{mg}, 59 \%)$ and benzo[b]fluorenone $\mathbf{3 6}(3.4 \mathrm{mg}, 14 \%)$. Note that the $4.2: 1$ ratio of $\mathbf{3 9 f}$ to $\mathbf{3 6}$ that is reported in Table 2 reflects the average of 5 independent runs. 2,4-dimethoxy isomer: $\mathrm{mp} 190{ }^{\circ} \mathrm{C}(\mathrm{dec})$; IR (neat): 3195, $1633 \mathrm{~cm}^{-1} ;{ }^{1} \mathrm{H}$ NMR $\left(500 \mathrm{MHz}, \mathrm{CDCl}_{3}\right) \delta 10.68(\mathrm{~s}, 1 \mathrm{H}), 7.57(\mathrm{~d}, J=7.6 \mathrm{~Hz}$, $1 \mathrm{H}), 7.46(\mathrm{t}, J=8.2 \mathrm{~Hz}, 1 \mathrm{H}), 7.31(\mathrm{~d}, J=8.9 \mathrm{~Hz}, 1 \mathrm{H}), 6.99(\mathrm{~d}, J=8.3 \mathrm{~Hz}, 1 \mathrm{H}), 6.70(\mathrm{~s}, 1 \mathrm{H})$, $6.65(\mathrm{~s}, 1 \mathrm{H}), 6.59(\mathrm{~m}, 2 \mathrm{H}), 4.08(\mathrm{~s}, 3 \mathrm{H}), 3.89(\mathrm{~s}, 3 \mathrm{H}), 3.87(\mathrm{~s}, 3 \mathrm{H}), 3.72(\mathrm{~s}, 3 \mathrm{H}), 2.32(\mathrm{~s}$, $3 \mathrm{H}) ;{ }^{13} \mathrm{C}$ NMR $\left(125 \mathrm{MHz}, \mathrm{CDCl}_{3}\right) \delta 181.3,161.2,160.9,158.9,151.4,150.0,144.1,142.8$, 138.0, 136.5, 133.6, 131.5, 128.3, 121.8, 119.5, 118.8, 117.2, 116.8, 114.7, 114.5, 110.9, 104.5, 99.0, 56.5, 56.1, 55.6, 55.4, 21.8; 2,6-dimethoxy isomer: $\mathrm{mp} 180^{\circ} \mathrm{C}$ (dec); IR (neat): 3190, $1633 \mathrm{~cm}^{-1} ;{ }_{1}^{1} \mathrm{H}$ NMR $\left(500 \mathrm{MHz}, \mathrm{CDCl}_{3}\right) \delta 10.80(\mathrm{~s}, 1 \mathrm{H}), 7.58(\mathrm{~d}, J=8.1 \mathrm{~Hz}, 1 \mathrm{H}), 7.47(\mathrm{t}, J=$ $8.1 \mathrm{~Hz}, 1 \mathrm{H}), 7.30(\mathrm{t}, J=8.3 \mathrm{~Hz}, 1 \mathrm{H}), 6.99(\mathrm{~d}, J=8.2 \mathrm{~Hz}, 1 \mathrm{H}), 6.65(\mathrm{~d}, J=8.5 \mathrm{~Hz}, 2 \mathrm{H}) 6.64$ $(\mathrm{s}, 1 \mathrm{H}), 6.57(\mathrm{~s}, 1 \mathrm{H}), 4.08(\mathrm{~s}, 3 \mathrm{H}), 3.89(\mathrm{~s}, 3 \mathrm{H}), 3.68(\mathrm{~s}, 6 \mathrm{H}), 2.30(\mathrm{~s}, 3 \mathrm{H}) ;{ }^{13} \mathrm{C}$ NMR $(125 \mathrm{MHz}$, $\left.\mathrm{CDCl}_{3}\right) \delta 181.1,161.1,158.5,151.5,150.0 .144 .0,130.4,138.1,136.7,136.3,133.6,129.1$, 121.6, 119.5, 118.5, 117.2, 114.9, 114.5, 113.7, 113.3, 110.9, 110.6, 104.3, 56.2, 56.1, 56.0, 21.8; ESI m/z relative intensity $457\left(\mathrm{MH}^{+} 30\right)$; TOFHRMS (+ESI) Calcd for $\mathrm{C}_{28} \mathrm{H}_{25} \mathrm{O}_{6}$ : 457.1651, Found 457.1653.

\section{5-(5-Hydroxy-4,9-dimethoxy-2-methyl-10-oxo-10H-benzo[b]fluoren-11-yl)isophthalonitrile $(39 \mathrm{~g})$}

Due to the insolubility of 1,3-dicyanobenzene in benzene at $80^{\circ} \mathrm{C}$, the following experiment was run at a 13:1 ratio of benzene:1,3-dicyanobenzene. Solid AIBN (11.0 mg, $0.066 \mathrm{mmol})$ was added portionwise over a period of $1 \mathrm{~h}$ to a stirring solution of diazoparaquinone $\mathbf{2 9}$ (20.0 $\mathrm{mg}, 0.060 \mathrm{mmol}), 1,3$-dicyanobenzene $(0.11 \mathrm{~g}, 0.86 \mathrm{mmol})$ and $\mathrm{Bu}_{3} \mathrm{SnH}(0.018 \mathrm{~mL}, 0.066$ $\mathrm{mmol})$ in benzene $(1.0 \mathrm{~mL}, 11 \mathrm{mmol})$ at $80^{\circ} \mathrm{C}$. When the addition was complete, the reaction solution was allowed to cool to room temperature. After reaching room temperature the reaction mixture was diluted with $\mathrm{CH}_{2} \mathrm{Cl}_{2}$ and purified with flash column chromatography, eluting with an increasing percentage of EtOAc from $0 \%$ to $10 \%$ in $\mathrm{CH}_{2} \mathrm{Cl}_{2}$. Purification furnished a 1:2.2 mixture of benzo[b]fluorenone $39 \mathrm{~g}(2,4: 2,6 ; 3,5=24: 76: 0)(6.5 \mathrm{mg}, 24 \%)$ and benzo[b] fluorenone 36 (12.4 mg, 52\%). The ratio of 39g:36, extrapolated to equimolar amounts of benzene and 1,3-dicyanobenzene, is calculated to be $6.0: 1$. Note that the $6.1: 1$ ratio of $\mathbf{3 9 g}$ to 36 that is reported in Table 2 reflects the average of 5 independent runs. 39g isomers were separated via preparative TLC (20\% EtOAc in benzene). 2,4-dicyano isomer: $\mathrm{mp} 270{ }^{\circ} \mathrm{C}(\mathrm{dec})$; IR (neat): 3213, 2526, $1633 \mathrm{~cm}^{-1} ;{ }^{1} \mathrm{H}$ NMR $\left(500 \mathrm{MHz}, \mathrm{CDCl}_{3}\right) \delta 10.97(\mathrm{~s}, 1 \mathrm{H}), 8.04(\mathrm{~s}, 1 \mathrm{H})$, $7.91(\mathrm{~d}, J=8.1 \mathrm{~Hz}, 1 \mathrm{H}), 7.63(\mathrm{~d}, J=8.1 \mathrm{~Hz}, 1 \mathrm{H}), 7.61(\mathrm{~d}, J=7.3 \mathrm{~Hz}, 1 \mathrm{H}), 7.53(\mathrm{t}, J=8.1 \mathrm{~Hz}$, $1 \mathrm{H}), 7.06(\mathrm{~d}, J=8.1 \mathrm{~Hz}, 1 \mathrm{H}), 6.72(\mathrm{~s}, 1 \mathrm{H}), 6.54(\mathrm{~s}, 1 \mathrm{H}), 4.13(\mathrm{~s}, 3 \mathrm{H}), 3.93(\mathrm{~s}, 3 \mathrm{H}), 2.35(\mathrm{~s}$, $3 \mathrm{H}) ;{ }^{13} \mathrm{C}$ NMR $\left(125 \mathrm{MHz}, \mathrm{CDCl}_{3}\right) \delta 181.4,161.5,153.7,151.7,144.6,141.8,138.9,137.4$, 136.2, 136.2, 135.3, 134.8, 131.4, 131.3, 120.58, 119.6, 118.1, 117.2, 117.1, 116.2, 115.6, 115.0, 114.0, 112.3, 111.5, 56.6, 56.3, 21.8; 2,6-isomer: $\mathrm{mp} 290^{\circ} \mathrm{C}$ (dec); IR (neat): 3213 , 2238, $1631 \mathrm{~cm}^{-1} ;{ }^{1} \mathrm{H}$ NMR (500 MHz, $\left.\mathrm{CDCl}_{3}\right) \delta 10.99(\mathrm{~s}, 1 \mathrm{H}), 7.96(\mathrm{~d}, J=8.0 \mathrm{~Hz}, 1 \mathrm{H}), 7.62$ $(\mathrm{d}, J=8.2 \mathrm{~Hz}, 1 \mathrm{H}), 7.60(\mathrm{t}, J=7.9 \mathrm{~Hz}, 1 \mathrm{H}), 7.53(\mathrm{~d}, J=8.2 \mathrm{~Hz}, 1 \mathrm{H}), 7.06(\mathrm{~d}, J=8.4 \mathrm{~Hz}, 2 \mathrm{H})$ $6.72(\mathrm{~s}, 1 \mathrm{H}), 6.48(\mathrm{~s}, 1 \mathrm{H}), 4.13(\mathrm{~s}, 3 \mathrm{H}), 3.93(\mathrm{~s}, 3 \mathrm{H}), 2.34(\mathrm{~s}, 3 \mathrm{H}) ;{ }^{13} \mathrm{C}$ NMR $(125 \mathrm{MHz}$, $\left.\mathrm{CDCl}_{3}\right) \delta 161.5,153.9,151.7,144.4,141.5,138.8,136.5,136.3,135.0,134.8,132.2,131.9$, 128.4, 120.5, 119.6, 118.2, 117.1, 116.4, 115.5, 115.0, 114.1, 111.6, 56.6, 56.4, 21.9; ESI m/ $z$ relative intensity $469\left(\mathrm{MNa}^{+} 100\right)$; TOFHRMS (+ESI) Calcd for $\mathrm{C}_{28} \mathrm{H}_{18} \mathrm{~N}_{2} \mathrm{O}_{4} \mathrm{Na}$ : 469.1164 , Found 469.1156.

\section{C(11) Dimer of 5-Hydroxy-4,9-dimethoxy-2-methyl-benzo[b]fluoren-10-one (49)}

Following General Procedure 2, in many of the solvent competition experiments aimed at converting diazoparaquinone $29(20 \mathrm{mg}, 0.06 \mathrm{mmol})$ to the aromatic solvent trapped adducts 
$(36+39 \mathbf{a}-\mathbf{g})$, the dimeric species $(\mathbf{4 9})$ was isolated as a minor product $(0-3.3 \mathrm{mg}, 0-15 \%): \mathrm{mp}$ $210^{\circ} \mathrm{C}$ (dec); IR (neat): $3414,2921,1626 \mathrm{~cm}^{-1}$; ${ }^{1} \mathrm{H}$ NMR $\left(300 \mathrm{MHz}, \mathrm{CDCl}_{3}\right) \delta 10.64(\mathrm{~s}, 1 \mathrm{H})$, $7.59(\mathrm{~d}, J=7.9 \mathrm{~Hz}, 1 \mathrm{H}), 7.47(\mathrm{t}, J=8.17 \mathrm{~Hz}, 1 \mathrm{H}), 6.96(\mathrm{~d}, J=7.7 \mathrm{~Hz}, 1 \mathrm{H}), 6.62(\mathrm{~d}, J=8.1$ $\mathrm{Hz}, 1 \mathrm{H}), 4.10(\mathrm{~s}, 3 \mathrm{H}), 3.83(\mathrm{~s}, 3 \mathrm{H}), 2.23(\mathrm{~s}, 3 \mathrm{H}),{ }^{13} \mathrm{C} \mathrm{NMR}\left(75 \mathrm{MHz}, \mathrm{CDCl}_{3}\right) \delta 180.8,161.2$, 151.6, 150.2, 142.7, 141.2, 138.3, 136.7, 133.8, 131.1, 121.3, 120.2, 118.3, 117.3, 115.0, 114.4, $111.1,56.5,56.1,21.8 ; \mathrm{ESI} \mathrm{m} / z$ relative intensity $639\left(\mathrm{MH}^{+} 100\right)$; TOFHRMS (+ESI) Calcd for $\mathrm{C}_{40} \mathrm{H}_{31} \mathrm{O}_{8}$ : 639.2019, Found 639.2047.

\section{5-Hydroxy-4,9-dimethoxy-2-methyl-11-phenylselanyl-benzo[b]fluoren-10-one (51)}

A solution of AIBN $(11.0 \mathrm{mg}, 0.067 \mathrm{mmol})$ in benzene $(1 \mathrm{~mL})$ was added over the period of 1 $\mathrm{h}$ to a stirring solution of diazoparaquinone $29(20 \mathrm{mg}, 0.06 \mathrm{mmol}), \mathrm{Bu}_{3} \mathrm{SnH}(0.018 \mathrm{~mL}, 0.067$ $\mathrm{mmol})$, and diphenyl diselenide $(0.112 \mathrm{mg}, 0.36 \mathrm{mmol})$ at $80^{\circ} \mathrm{C}$. The light red mixture turned to a dark red/purple color upon addition of AIBN. When the addition was complete, the reaction solution was allowed to cool to room temperature. After reaching room temperature the reaction mixture was diluted with $\mathrm{CH}_{2} \mathrm{Cl}_{2}$ and poured onto a $\mathrm{AgNO}_{3}$ impregnated silica gel column (silica gel column chromatography alone was insufficient for separation) and purified by eluting with $\mathrm{CH}_{2} \mathrm{Cl}_{2}$ with an increasing percentage of EtOAc from $0 \%$ to $10 \%$. Purification furnished the benzene trapped adduct $\mathbf{3 6}(5.0 \mathrm{mg}, 21 \%)$, and the phenylselenide trapped adduct 51 (10 mg, 35\%): $\mathrm{mp} 162{ }^{\circ} \mathrm{C}$ (dec); IR (neat): $3414,2919,1631,1607,1583 \mathrm{~cm}^{-1} ;{ }^{1} \mathrm{H}$ NMR $\left(500 \mathrm{MHz}, \mathrm{CDCl}_{3}\right) \delta 10.42(\mathrm{~s}, 1 \mathrm{H}), 7.80(\mathrm{~d}, J=7.0 \mathrm{~Hz}, 1 \mathrm{H}), 7.62(\mathrm{~d}, J=8.3 \mathrm{~Hz}, 2 \mathrm{H}), 7.52(\mathrm{t}$, $J=8.1 \mathrm{~Hz}, 1 \mathrm{H}), 7.44(\mathrm{t}, J=7.2 \mathrm{~Hz}, 1 \mathrm{H}), 7.35(\mathrm{t}, J=7.1 \mathrm{~Hz}, 2 \mathrm{H}), 7.06(\mathrm{~d}, J=8.2 \mathrm{~Hz}, 1 \mathrm{H})$, $6.53(\mathrm{~s}, 1 \mathrm{H}), 5.75(\mathrm{~s}, 1 \mathrm{H}), 4.03(\mathrm{~s}, 3 \mathrm{H}), 4.02(\mathrm{~s}, 3 \mathrm{H}), 1.96(\mathrm{~s}, 3 \mathrm{H}) ;{ }^{13} \mathrm{C}$ NMR $(125 \mathrm{MHz}$, $\left.\mathrm{CDCl}_{3}\right) \delta 180.6,161.3,151.1,147.6,143.8,142.4,137.4,136.4,136.3,133.7,131.7,129.1$, $128.9,128.7,121.3,120.1,117.2,113.6,113.5,113.4,110.9,56.4,56.1,21.7 ;$ ESI $\mathrm{m} / z$ relative intensity $477\left(\mathrm{MH}^{+} 100\right)$; TOFHRMS (+ESI) Calcd for $\mathrm{C}_{26} \mathrm{H}_{21} \mathrm{O}_{4} \mathrm{Se}$ : 477.0605 , Found 477.0615 .

\section{1-Benzylsulfanyl-4,9-dimethoxy-2-methyl-11-phenyl-benzo[b]fluorene-5,10-diol (53), and 11-Benzylsulfanyl-4,9-dimethoxy-2-methyl-11H-benzo[b]fluorene-5,10-diol (54)}

A Solution of AIBN $(11.0 \mathrm{mg}, 0.067 \mathrm{mmol})$ in benzene $(1 \mathrm{~mL})$ was added over the period of $1 \mathrm{~h}$ to a stirring solution of diazoparaquinone $29(20 \mathrm{mg}, 0.06 \mathrm{mmol}), \mathrm{Bu}_{3} \mathrm{SnH}(0.018 \mathrm{~mL}$, $0.067 \mathrm{mmol}, 1.1$ equivalents) (or 12 equivalents), and benzyl mercaptan $(0.077 \mathrm{~mL}, 0.6 \mathrm{mmol})$ at $80{ }^{\circ} \mathrm{C}$. The light red mixture turned to a dark red color upon addition of AIBN. When the addition was complete, the reaction solution was allowed to cool to room temperature. After reaching room temperature the reaction mixture was diluted with $\mathrm{CH}_{2} \mathrm{Cl}_{2}$ and poured onto a silica gel column and purified by eluting with hexanes/ $\mathrm{CH}_{2} \mathrm{Cl}_{2}$ (1:1) followed by $\mathrm{CH}_{2} \mathrm{Cl}_{2}$ with an increasing percentage of EtOAc from $0 \%$ to $5 \%$. Oxidation of the air sensitive hydroquinone $\mathbf{5 4}$ was minimized during purification by employing $\mathrm{N}_{2}$ purged solvents and using low pressure $\mathrm{N}_{2}$ gas for the chromatography. Purification furnished the benzene trapped adduct $\mathbf{3 6}(3.5 \mathrm{mg}$, 15\%), the benzene/benzyl mercaptan trapped adduct $\mathbf{5 3}(6.7 \mathrm{mg}, 22 \%)$ and the benzyl mercaptan trapped adduct 54 (12.5 mg, 46\%). 53: mp $260^{\circ} \mathrm{C}$ (dec); IR (neat): 3378, 3307, 2922, 1644, $1610 \mathrm{~cm}^{-1} ;{ }^{1} \mathrm{H}$ NMR $\left(500 \mathrm{MHz}, \mathrm{CDCl}_{3}\right) \delta 9.85(\mathrm{~s}, 1 \mathrm{H}), 9.12(\mathrm{~s}, 1 \mathrm{H}) 7.95(\mathrm{~d}, J=$ $8.5 \mathrm{~Hz}, 1 \mathrm{H}), 7.50(\mathrm{~d}, J=8.6 \mathrm{~Hz}, 2 \mathrm{H}), 7.33(\mathrm{t}, J=7.8 \mathrm{~Hz}, 1 \mathrm{H}), 7.19-7.27(\mathrm{~m}, 3 \mathrm{H}), 6.94-7.04$ $(\mathrm{m}, 5 \mathrm{H}), 6.91(\mathrm{~s}, 1 \mathrm{H}), 6.79(\mathrm{~d}, J=7.7 \mathrm{~Hz}, 1 \mathrm{H}), 6.65(\mathrm{~s}, 1 \mathrm{H}), 4.16(\mathrm{~s}, 3 \mathrm{H}), 3.96(\mathrm{~s}, 3 \mathrm{H}), 3.25$ $(\mathrm{d}, J=12.6 \mathrm{~Hz}, 1 \mathrm{H}), 3.14(\mathrm{~d}, J=12.6 \mathrm{~Hz}, 1 \mathrm{H}), 2.30(\mathrm{~s}, 3 \mathrm{H}) ;{ }^{13} \mathrm{C} \mathrm{NMR}\left(125 \mathrm{MHz}, \mathrm{CDCl}_{3}\right) \delta$ 156.5, 152.6, 151.0, 143.5, 141.4, 139.8, 138.9, 137.6, 128.8, 128.3, 128.1, 127.7, 126.9, 126.8, 126.2, 126.0, 125.0, 123.8, 120.4, 120.2, 116.7, 115.8, 111.3, 104.9, 64.0, 56.5, 55.8, 34.4, 29.7; ESI m/z relative intensity $543\left(\mathrm{MNa}^{+} 40\right)$; TOFHRMS (+ESI) Calcd for $\mathrm{C}_{33} \mathrm{H}_{28} \mathrm{O}_{4} \mathrm{SNa}$ : 543.1606, Found 543.1647; 54: $\mathrm{mp} 160{ }^{\circ} \mathrm{C}$ (dec); IR (neat): 3389, 3311, 2921, 1611, 1580 $\mathrm{cm}^{-1} ;{ }^{1} \mathrm{H}$ NMR $\left(500 \mathrm{MHz}, \mathrm{CDCl}_{3}\right) \delta 9.64(\mathrm{~s}, 1 \mathrm{H}), 9.26(\mathrm{~s}, 1 \mathrm{H}), 7.86(\mathrm{~d}, J=8.5 \mathrm{~Hz}, 1 \mathrm{H}), 7.26$ (t, $J=7.8 \mathrm{~Hz}, 1 \mathrm{H}), 6.89-7.03(\mathrm{~m}, 6 \mathrm{H}), 6.76(\mathrm{~d}, J=7.6 \mathrm{~Hz}, 1 \mathrm{H}), 6.62(\mathrm{~s}, 1 \mathrm{H}), 5.05(\mathrm{~s}, 1 \mathrm{H}), 4.02$ $(\mathrm{s}, 3 \mathrm{H}), 3.99(\mathrm{~s}, 3 \mathrm{H}), 3.40(\mathrm{~d}, J=12.9 \mathrm{~Hz}, 1 \mathrm{H}), 3.22(\mathrm{~d}, J=12.9 \mathrm{~Hz}, 1 \mathrm{H}), 2.32(\mathrm{~s}, 3 \mathrm{H}) ;{ }^{13} \mathrm{C}$ 
$\operatorname{NMR}\left(125 \mathrm{MHz}, \mathrm{CDCl}_{3}\right) \delta 156.3,151.3,147.4,143.5,139.3,139.1,138.4,128.9,128.0,127.9$, 126.3, 125.1, 124.8, 122.6, 120.8, 120.3, 116.8, 115.3, 111.3, 104.9, 56.5, 56.0, 48.0, 33.5, 29.7; ESI m/z relative intensity $467\left(\mathrm{MNa}^{+} 95\right)$; TOFHRMS (+ESI) Calcd for $\mathrm{C}_{27} \mathrm{H}_{24} \mathrm{O}_{4} \mathrm{SNa}$ : 467.1293, Found 467.1301.

\section{Control Experiment: Benzyl Mercaptan Addition to Diazoparaquinone 29 with no Radical- Generating Ingredients}

Benzyl mercaptan $(0.019 \mathrm{~mL}, 0.15 \mathrm{mmol})$ was added to a stirring solution of diazoparaquinone $29(5.0 \mathrm{mg}, 0.015 \mathrm{mmol})$ at $80^{\circ} \mathrm{C}$. The light red mixture was stirred at $80^{\circ} \mathrm{C}$ for $1 \mathrm{~h}$. Following $1 \mathrm{~h}$ of stirring, the reaction solution was allowed to cool to room temperature. After reaching room temperature the reaction mixture was diluted with $\mathrm{CH}_{2} \mathrm{Cl}_{2}$ and poured onto a silica gel column and purified by eluting with hexanes $/ \mathrm{CH}_{2} \mathrm{Cl}_{2}$ (1:1), followed by $\mathrm{CH}_{2} \mathrm{Cl}_{2}$ with an increasing percentage of EtOAc from $0 \%$ to 5\%. Purification provided diazoparaquinone 29 (4.7 $\mathrm{mg}, 94 \%)$ unchanged.

\section{Control Experiment: Benzyl Mercaptan Addition to Prekinamycin (5) with No Radical- Generating Ingredients}

Benzyl mercaptan $(0.015 \mathrm{~mL}, 0.12 \mathrm{mmol})$ was added to a stirring solution of prekinamycin (5) $(3.7 \mathrm{mg}, 0.012 \mathrm{mmol})$ at $80{ }^{\circ} \mathrm{C}$. The dark purple/brown mixture was stirred at $80^{\circ} \mathrm{C}$ for 1 $\mathrm{h}$. Following $1 \mathrm{~h}$ of stirring, the reaction solution was allowed to cool to room temperature. After reaching room temperature the reaction mixture was diluted with $\mathrm{CH}_{2} \mathrm{Cl}_{2}$ and poured onto a silica gel column and purified by eluting with hexanes $/ \mathrm{CH}_{2} \mathrm{Cl}_{2}(1: 1)$, followed by $\mathrm{CH}_{2} \mathrm{Cl}_{2}$ with an increasing percentage of EtOAc from $0 \%$ to $5 \%$. Purification provided prekinamycin (5) (3.7 mg, 100\%) unchanged.

\section{1-Benzylsulfanyl-4,9-dimethoxy-2-methyl-11-phenyl-benzo[b]fluorene-5,10-diol (53) from benzene trapped adduct (36)}

Benzyl mercaptan $(0.100 \mathrm{~mL}, 0.80 \mathrm{mmol})$ was added to a stirring solution of benzene trapped adduct $36(3.0 \mathrm{mg}, 0.008 \mathrm{mmol})$ at $80{ }^{\circ} \mathrm{C}$. The bright red solution turned to a dark red solution over the $2 \mathrm{~h}$ of stirred at $80^{\circ} \mathrm{C}$. Upon consumption of the starting material by TLC, the reaction solution was allowed to cool to room temperature. After reaching room temperature the reaction mixture was diluted with $\mathrm{CH}_{2} \mathrm{Cl}_{2}$ and poured onto a silica gel column and purified by eluting with hexanes $/ \mathrm{CH}_{2} \mathrm{Cl}_{2}$ (1:1), followed by $\mathrm{CH}_{2} \mathrm{Cl}_{2}$ with an increasing percentage of EtOAc from $0 \%$ to $5 \%$. Purification afforded benzyl mercaptan addition product $53(3.7 \mathrm{mg}, 94 \%)$.

\section{Deuterium Labeling Experiment: $\mathrm{PhCH}_{2} \mathrm{SD} / \mathrm{Bu}_{3} \mathrm{SnH} / \mathrm{AIBN}$}

A Solution of AIBN $(11.0 \mathrm{mg}, 0.067 \mathrm{mmol})$ in benzene $(1 \mathrm{~mL})$ was added over the period of $1 \mathrm{~h}$ to a stirring solution of diazoparaquinone $29(20 \mathrm{mg}, 0.06 \mathrm{mmol}), \mathrm{Bu}_{3} \mathrm{SnH}(0.018 \mathrm{~mL}$, $0.067 \mathrm{mmol})$, and $\mathrm{PhCH}_{2} \mathrm{SD}(0.077 \mathrm{~mL}, 0.6 \mathrm{mmol})$ at $80^{\circ} \mathrm{C}$. The light red mixture turned to a dark red color upon addition of AIBN. When the addition was complete, the reaction solution was allowed to cool to room temperature. After reaching room temperature the reaction mixture was diluted with $\mathrm{CH}_{2} \mathrm{Cl}_{2}$ and poured onto a silica gel column and purified by eluting with hexanes $/ \mathrm{CH}_{2} \mathrm{Cl}_{2}$ (1:1), followed by $\mathrm{CH}_{2} \mathrm{Cl}_{2}$ with an increasing percentage of EtOAc from $0 \%$ to $5 \%$. Purification furnished benzyl mercaptan trapped adduct $\mathbf{5 4}$ (33\% by ${ }^{1} \mathrm{H}$ NMR) with 46 $\%$ deuterium incorporation at $\mathrm{C}(11) .{ }^{1} \mathrm{H}$ NMR $\left(400 \mathrm{MHz}, \mathrm{CDCl}_{3}\right) \delta 9.64(\mathrm{~s}, 1 \mathrm{H}), 9.26(\mathrm{~s}, 1 \mathrm{H})$, $7.86(\mathrm{~d}, J=8.5 \mathrm{~Hz}, 1 \mathrm{H}), 7.26(\mathrm{t}, J=7.8 \mathrm{~Hz}, 1 \mathrm{H}), 6.89-7.03(\mathrm{~m}, 6 \mathrm{H}), 6.76(\mathrm{~d}, J=7.6 \mathrm{~Hz}, 1 \mathrm{H})$, $6.62(\mathrm{~s}, 1 \mathrm{H}), 5.05(\mathrm{~s}, 0.54 \mathrm{H}), 4.02(\mathrm{~s}, 3 \mathrm{H}), 3.99(\mathrm{~s}, 3 \mathrm{H}), 3.40(\mathrm{~d}, J=12.9 \mathrm{~Hz}, 1 \mathrm{H}), 3.22(\mathrm{~d}, J=$ $12.9 \mathrm{~Hz}, 1 \mathrm{H}), 2.32(\mathrm{~s}, 3 \mathrm{H})$. 


\section{Deuterium Labeling Experiment: $\mathrm{PhCH}_{2} \mathrm{SH} / \mathrm{Bu}_{3} \mathrm{SnD} / \mathrm{AIBN}$}

A Solution of AIBN $(11.0 \mathrm{mg}, 0.067 \mathrm{mmol})$ in benzene $(1 \mathrm{~mL})$ was added over the period of $1 \mathrm{~h}$ to a stirring solution of diazoparaquinone $29(20 \mathrm{mg}, 0.06 \mathrm{mmol}), \mathrm{Bu}_{3} \mathrm{SnD}(0.018 \mathrm{~mL}$, $0.067 \mathrm{mmol})$, and $\mathrm{PhCH}_{2} \mathrm{SH}(0.077 \mathrm{~mL}, 0.6 \mathrm{mmol})$ at $80^{\circ} \mathrm{C}$. The light red mixture turned to a dark brown color upon addition of AIBN. When the addition was complete, the reaction solution was allowed to cool to room temperature. After reaching room temperature the reaction mixture was diluted with $\mathrm{CH}_{2} \mathrm{Cl}_{2}$ and poured onto a silica gel column and purified by eluting with hexanes $/ \mathrm{CH}_{2} \mathrm{Cl}_{2}$ (1:1), followed by $\mathrm{CH}_{2} \mathrm{Cl}_{2}$ with an increasing percentage of EtOAc from $0 \%$ to $5 \%$. Purification furnished benzyl mercaptan trapped adduct 54 (40\% by ${ }^{1} \mathrm{H}$ NMR) with $27 \%$ deuterium incorporation at $\mathrm{C}(11) .{ }^{1} \mathrm{H}$ NMR $\left(400 \mathrm{MHz}, \mathrm{CDCl}_{3}\right) \delta 9.64(\mathrm{~s}, 1 \mathrm{H}), 9.26(\mathrm{~s}$, $1 \mathrm{H}), 7.86(\mathrm{~d}, J=8.5 \mathrm{~Hz}, 1 \mathrm{H}), 7.26(\mathrm{t}, J=7.8 \mathrm{~Hz}, 1 \mathrm{H}), 6.89-7.03(\mathrm{~m}, 6 \mathrm{H}), 6.76(\mathrm{~d}, J=7.6 \mathrm{~Hz}$, $1 \mathrm{H}), 6.62(\mathrm{~s}, 1 \mathrm{H}), 5.05(\mathrm{~s}, 0.73 \mathrm{H}), 4.02(\mathrm{~s}, 3 \mathrm{H}), 3.99(\mathrm{~s}, 3 \mathrm{H}), 3.40(\mathrm{~d}, J=12.9 \mathrm{~Hz}, 1 \mathrm{H}), 3.22$ $(\mathrm{d}, J=12.9 \mathrm{~Hz}, 1 \mathrm{H}), 2.32(\mathrm{~s}, 3 \mathrm{H})$.

\section{Deuterium Labeling Experiment: $\mathrm{PhCH}_{2} \mathrm{SD} / \mathrm{Bu}_{3} \mathrm{SnD} / \mathrm{AIBN}$}

A Solution of AIBN $(11.0 \mathrm{mg}, 0.067 \mathrm{mmol})$ in benzene $(1 \mathrm{~mL})$ was added over the period of $1 \mathrm{~h}$ to a stirring solution of diazoparaquinone $29(20 \mathrm{mg}, 0.06 \mathrm{mmol}), \mathrm{Bu}_{3} \mathrm{SnD}(0.018 \mathrm{~mL}$, $0.067 \mathrm{mmol})$, and $\mathrm{PhCH}_{2} \mathrm{SD}(0.077 \mathrm{~mL}, 0.6 \mathrm{mmol})$ at $80^{\circ} \mathrm{C}$. The light red mixture turned to a dark brown color upon addition of AIBN. When the addition was complete, the reaction solution was allowed to cool to room temperature. After reaching room temperature the reaction mixture was diluted with $\mathrm{CH}_{2} \mathrm{Cl}_{2}$ and poured onto a silica gel column and purified by eluting with hexanes/ $\mathrm{CH}_{2} \mathrm{Cl}_{2}$ (1:1) followed $\mathrm{CH}_{2} \mathrm{Cl}_{2}$ with an increasing percentage of EtOAc from $0 \%$ to $5 \%$. Purification furnished benzyl mercaptan trapped adduct 54 (46\% by ${ }^{1} \mathrm{H}$ NMR) with $76 \%$ deuterium incorporation at $\mathrm{C}(11) .{ }^{1} \mathrm{H}$ NMR $\left(400 \mathrm{MHz}, \mathrm{CDCl}_{3}\right) \delta 9.64(\mathrm{~s}, 1 \mathrm{H}), 9.26(\mathrm{~s}$, $1 \mathrm{H}), 7.86(\mathrm{~d}, J=8.5 \mathrm{~Hz}, 1 \mathrm{H}), 7.26(\mathrm{t}, J=7.8 \mathrm{~Hz}, 1 \mathrm{H}), 6.89-7.03(\mathrm{~m}, 6 \mathrm{H}), 6.76(\mathrm{~d}, J=7.6 \mathrm{~Hz}$, $1 \mathrm{H}), 6.62(\mathrm{~s}, 1 \mathrm{H}), 5.05(\mathrm{~s}, 0.24 \mathrm{H}), 4.02(\mathrm{~s}, 3 \mathrm{H}), 3.99(\mathrm{~s}, 3 \mathrm{H}), 3.40(\mathrm{~d}, J=12.9 \mathrm{~Hz}, 1 \mathrm{H}), 3.22$ (d, $J=12.9 \mathrm{~Hz}, 1 \mathrm{H}), 2.32(\mathrm{~s}, 3 \mathrm{H})$.

\section{Deuterium-Crossover Control Experiment: $\mathrm{PhCH}_{2} \mathrm{SD} / \mathrm{Bu}_{3} \mathrm{SnH} / \mathrm{AIBN}$}

AIBN (12.0 mg, $0.073 \mathrm{mmol}), \mathrm{PhCH}_{2} \mathrm{SD}(0.010 \mathrm{~mL}, 0.073 \mathrm{mmol})$, and $\mathrm{Bu}_{3} \mathrm{SnH}(0.020 \mathrm{~mL}$, $0.073 \mathrm{mmol}$ ) were dissolved in $\mathrm{d}_{6}$-benzene $(1 \mathrm{~mL})$ and inspected by ${ }^{1} \mathrm{H} \mathrm{NMR}$, and it was noted that a triplet at $1.43 \mathrm{ppm}\left(\mathrm{PhCH}_{2} \mathrm{~S} \underline{\mathrm{H}}\right)$ was absent. The reaction solution was then heated at 80 ${ }^{\circ} \mathrm{C}$ for $1 \mathrm{~h}$. After $1 \mathrm{~h}$ at $80^{\circ} \mathrm{C}$, close inspection of the ${ }^{1} \mathrm{H}$ NMR spectrum did not provide any evidence for a signal at $1.43 \mathrm{ppm}$.

\section{Deuterium-Crossover Control Experiment: $\mathrm{Bu}_{3} \mathrm{SnD} / \mathrm{PhCH}_{2} \mathrm{SH} / \mathrm{AIBN}$}

AIBN (12.0 mg, $0.073 \mathrm{mmol}), \mathrm{Bu}_{3} \mathrm{SnD}(0.020 \mathrm{~mL}, 0.073 \mathrm{mmol})$, and $\mathrm{PhCH}_{2} \mathrm{SH}(0.010 \mathrm{~mL}$, $0.073 \mathrm{mmol}$ ) were dissolved in $\mathrm{d}_{6}$-benzene $(1 \mathrm{~mL})$ and inspected by ${ }^{1} \mathrm{H} \mathrm{NMR}$, and the presence of a triplet at $1.43 \mathrm{ppm}(1 \mathrm{H})\left(\mathrm{PhCH}_{2} \mathrm{~S} \underline{\mathrm{H}}\right)$ was noted. The reaction solution was then heated at $80{ }^{\circ} \mathrm{C}$ for $1 \mathrm{~h}$. After $1 \mathrm{~h}$ at $80^{\circ} \mathrm{C}$, close inspection of the ${ }^{1} \mathrm{H}$ NMR spectrum revealed that the triplet at $1.43 \mathrm{ppm}$ remained and had not diminished in intensity.

\section{Supplementary Material}

Refer to Web version on PubMed Central for supplementary material.

\section{Acknowledgements}

Financial support from the National Institutes of Health, General Medical Sciences Division (GM 37861) is gratefully acknowledged. 


\section{References}

1. (a) Ito S, Matsuya T, Omura S, Otani M, Nakagawa A, Takeshima H, Iwai Y, Ohtani M, Hata T. Antibiot 1970;23:315-316. (b) Hata T, Omura S, Iwai Y, Nakagawa A, Otani M, Ito S, Matsuya T. Antibiot 1971;24:353-359. (c) Omura S, Nakagawa A, Yamada H, Hata T, Furusaki A, Watanabe T. Chem Pharm Bull 1973;21:931-940. [PubMed: 4727361]

2. He H, Ding W-D, Bernan VS, Richardson AD, Ireland CM, Greenstein M, Ellestad GA, Carter GT. J Am Chem Soc 2001;123:5362-5363. [PubMed: 11457405]

3. (a) Gould SJ, Chen J, Cone MC, Gore MP, Melville CR, Tamayo N. J Org Chem 1996;61:5720-5721. (b) Gould SJ. Chem Rev 1997;97:2499-2509. [PubMed: 11851467] and references cited therein. (c) Marco-Contelles J, Molina MT. Current Organic Chemistry 2003;7:1433-1442.

4. Isoprekinamycin: (a) Proteau PJ, Li Y, Chen J, Williamson RT, Gould SJ, Laufer RS, Dmitrienko GI. J Am Chem Soc 2000;122:8325-8326. Lagunamycin: (b) Imae K, Nihei Y, Oka M, Yamasaki T, Konishi M, Oki T. J Antibiot 1993;46:1031-1033. [PubMed: 8393849] Azaserine: (c) Fusari SA, Haskell TH, Frohardt RP, Bartz QR. Am Chem Soc 1954;76:2881-2883. 6-Diazo-5-oxo-L-norleucine: (d) Dion HW, Fusari SA, Jakubowski ZL, Zora JG, Bartz QR. J Am Chem Soc 78:1956. 3075-3077. SF2415A2 and congeners: (e) Gomi S, Ohuchi S, Sasaki T, Itoh J, Sezaki M. J Antibiot 1987;40:740749. [PubMed: 3610831] (f) Fukuda DS, Mynderse JS, Baker PJ, Berry DM, Boeck LD, Yao RC, Mertz FP, Nakatsukasa WM, Mabe J, Ott J, Counter FT, Ensminger PW, Allen NE, Alborn WE Jr, Hobbes JN Jr. J Antibiot 1990;43:623-633. [PubMed: 1696251]

5. Arya DP, Jebaratnam DJ. J Org Chem 1995;60:3268-3269.

6. (a) Stubbe J, Kozarich JW. Chem Rev 1987;87:1107-1136. (b) Murphy JA, Griffiths J. Nat Prod Reports 1993:551-564. (c) Dussy A, Meggars E, Giese B. J Am Chem Soc 1998;120:7399-7403.

7. Laufer RS, Dmitrienko GI. J Am Chem Soc 2002;124:1854-1855. [PubMed: 11866589]

8. (a) Danishefsky SJ, Schkeryantz JM. Synlett 1995:475-490. (b) Rajski SR, Williams RM. Chem Rev 1998;98:2723-2795. [PubMed: 11848977]

9. (a) Goldberg IH. Acc Chem Res 1991;24:191-198. (b) Myers AG. Tetrahedron Lett 1987;28:44934496.

10. Sugiyama H, Fujiwara T, Saito I. Tetrahedron Lett 1994;35:8825-8828.

11. (a) Woynarowski JM, Napier C, Koester SK, Chen S-F, Troyer D, Chapman W, MacDonald JR. Biochem Pharmacol 1997;54:1181-1193. [PubMed: 9416969] (b) Herzig MCS, Arnett B, MacDonald JR, Woynarowski JM. Biochem Pharmacol 1999;58:217-225. [PubMed: 10423161] (c) McMorris TC. Bioorg Med Chem 1999;1:881-886. [PubMed: 10400341]

12. (a) Kushida T, Uesugi M, Sugiura Y, Kigoshi H, Tanaka H, Hirokawa J, Ojika M, Yamada K. J Am Chem Soc 1994;116:479-486. (b) Hara M, Saitoh Y, Nakano H. Biochemistry 1990;29:5676-5681. [PubMed: 2383554] (c) Asai A, Saito H, Saitoh Y. Bioorg Med Chem 1997;5:723-729. [PubMed: 9158871] (d) Hara M, Yoshida M, Nakano H. Biochemistry 1990;29:10449-10455. [PubMed: 2271655] (e) Sugiyama H, Furiwara T, Ura A, Tashiro T, Yamamoto K, Kawanishi S, Saito I. Chem Res Toxicol 1994;7:673-683. [PubMed: 7841347]

13. Carney JR, Hong S-T, Gould SJ. Tetrahedron Lett 1997;38:3139-3142.

14. Hauser FM, Zhou M. J Org Chem 1996;61:5722.

15. Kim S, Cho JR. Bull Korean Chem Soc 1993;14:664-665.

16. Volkmann C, Rössner E, Metzler M, Zähner H, Zeeck A. Liebigs Ann 1995:1169-1172.

17. $\sigma$ values from: Hammett LP. J Am Chem Soc 1937;59:96-103. The raw [39]/[36] values were (1) divided by $1 / 6$ to compensate for the six equivalent positions of benzene, and (2) multiplied by the $\%$ para product from Table 2.

18. (a) Dannley RL, Gregg EC Jr, Phelps RE, Coleman CB. J Am Chem Soc 1954;76:445-448. (b) Dannley RL, Gregg EC Jr. J Am Chem Soc 1954;76:2997-3000. (c) Kryger RG, Lorand JP, Stevens NR, Herron NR. J Am Chem Soc 1977;99:7589-7600. (d) Madhavan V, Schuler RH, Fessenden RW. J Am Chem Soc 1978;100:888-893. (e) Traynham JG. Chem Rev 1979;79:323-330. (f) Scaiano JC, Stewart LC. J Am Chem Soc 1983;105:3609-3614. (g) Crich D, Hwang J-T. J Org Chem 1998;63:2765-2770. [PubMed: 11672154] (h) Martínez-Barrasa V, García de Viedma A, Burgos C, Alvarez-Builla J. Org Lett 2000;2:3933-3935. [PubMed: 11101457] (i) Núñez A, Sánchez A, Burgos C, Alvarez-Builla J. Tetrahedron 2004;60:6217-6224. (j) McLoughlin PTF, Clyne MA, Aldabbagh 
F. Tetrahedron 2004;60:8065-8071. (k) Liu, J-a; Petzold, CJ.; Ramirez-Arizmendi, LE.; Perez, J.; Kenttämaa, H. J Am Chem Soc 2005;127:12758-12759. [PubMed: 16159243]

19. Beckwith ALJ, Bowry VW, Bowman WR, Mann E, Parr J, Storey JMD. Angew Chem Int Ed 2004;43:95-98. and references cited therein.

20. Vernin G, Jauffred R, Ricard C, Dou HJM, Metzger J. J Chem Soc, Perkin Trans 1972;2:1145-1150.

21. Gould SJ, Melville CR. Tetrahedron Lett 1997;38:1473-1476. 


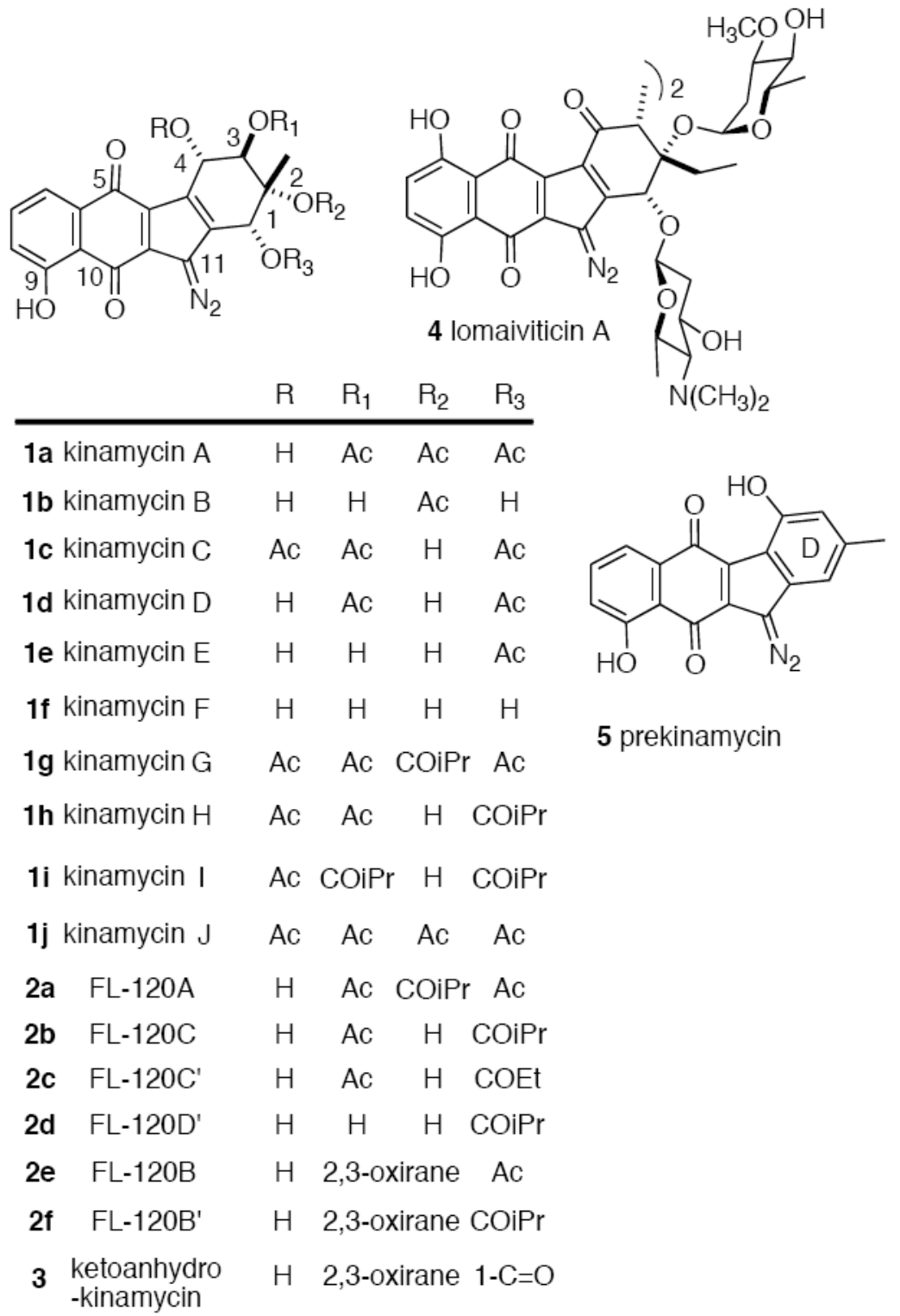

Figure 1.

Diazoparaquinone-containing natural products. 
<smiles>Cc1cc(O)c2c3c(=O)c4cccc(O)c4c=3c(=O)c(=[N+]=[N-])c2c1</smiles>

6 isoprekinamycin<smiles>CC(C)CC(C)/C=C/c1cc(=O)[nH]c2c(=O)c(=O)c(=[N+]=[N-])c(=O)c12</smiles>

7 lagunamycin<smiles>[X]C(=O)C=[W]</smiles>

$8 \mathbf{a} X=O$ azaserine $8 \mathbf{b} \mathrm{X}=\mathrm{CH}_{2}$ 6-diazo5-oxo-L-norleucine<smiles>CC(C)=CCC/C=C/CC12OC1(CC=C(C)C)C(=O)C1=C2C(=O)C(=[N+]=[N-])C(C)=C1O</smiles>

9 SF2415A2 + 4 similar congeners where further chemistry on the epoxide and side chain alkenes has occurred

Figure 2.

Diazo-containing natural products lacking the paraquinone function. 


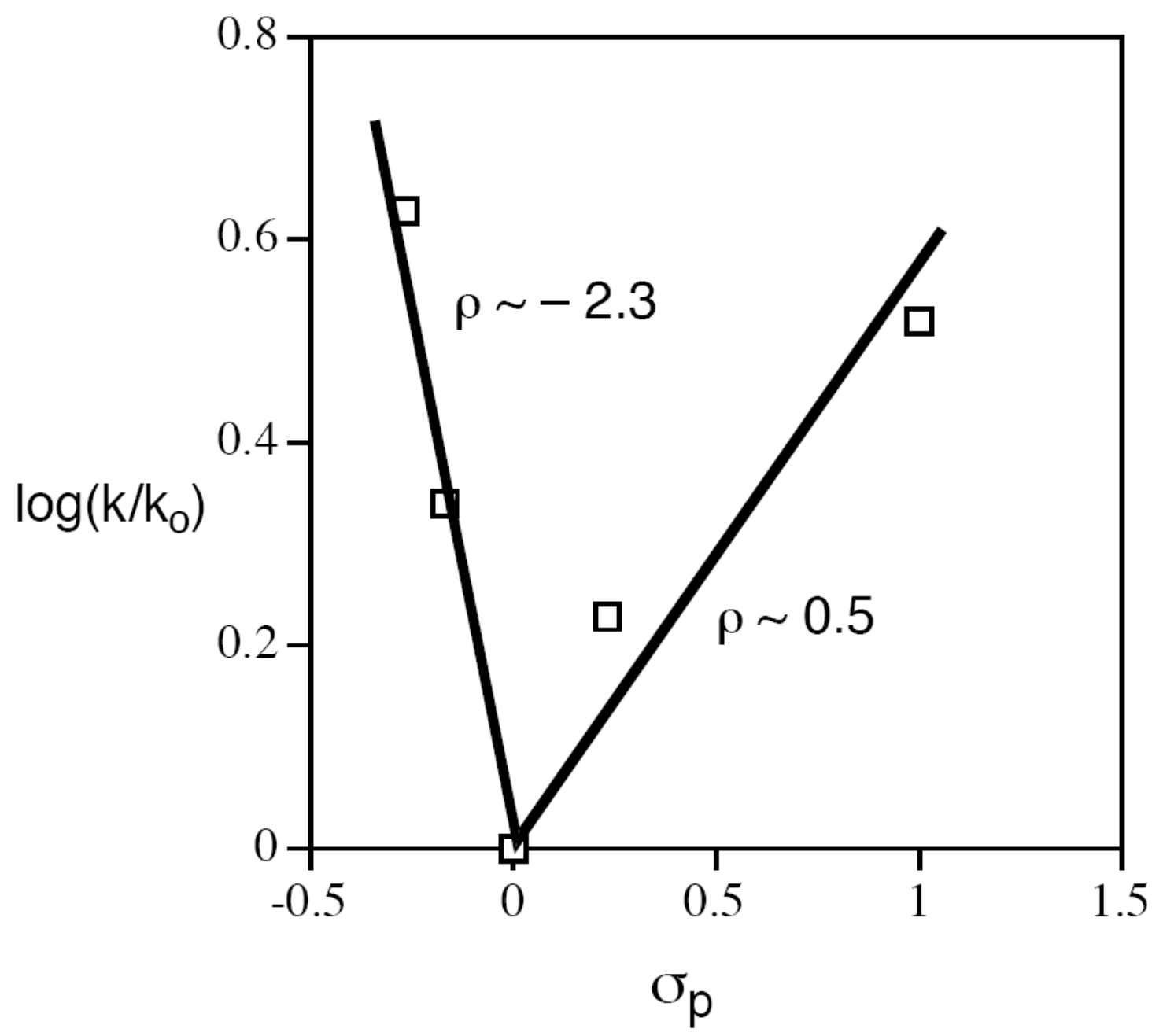

Figure 3.

Hammett study of the reaction between $\mathbf{2 9}$ and arene solvents under radical generating conditions. 

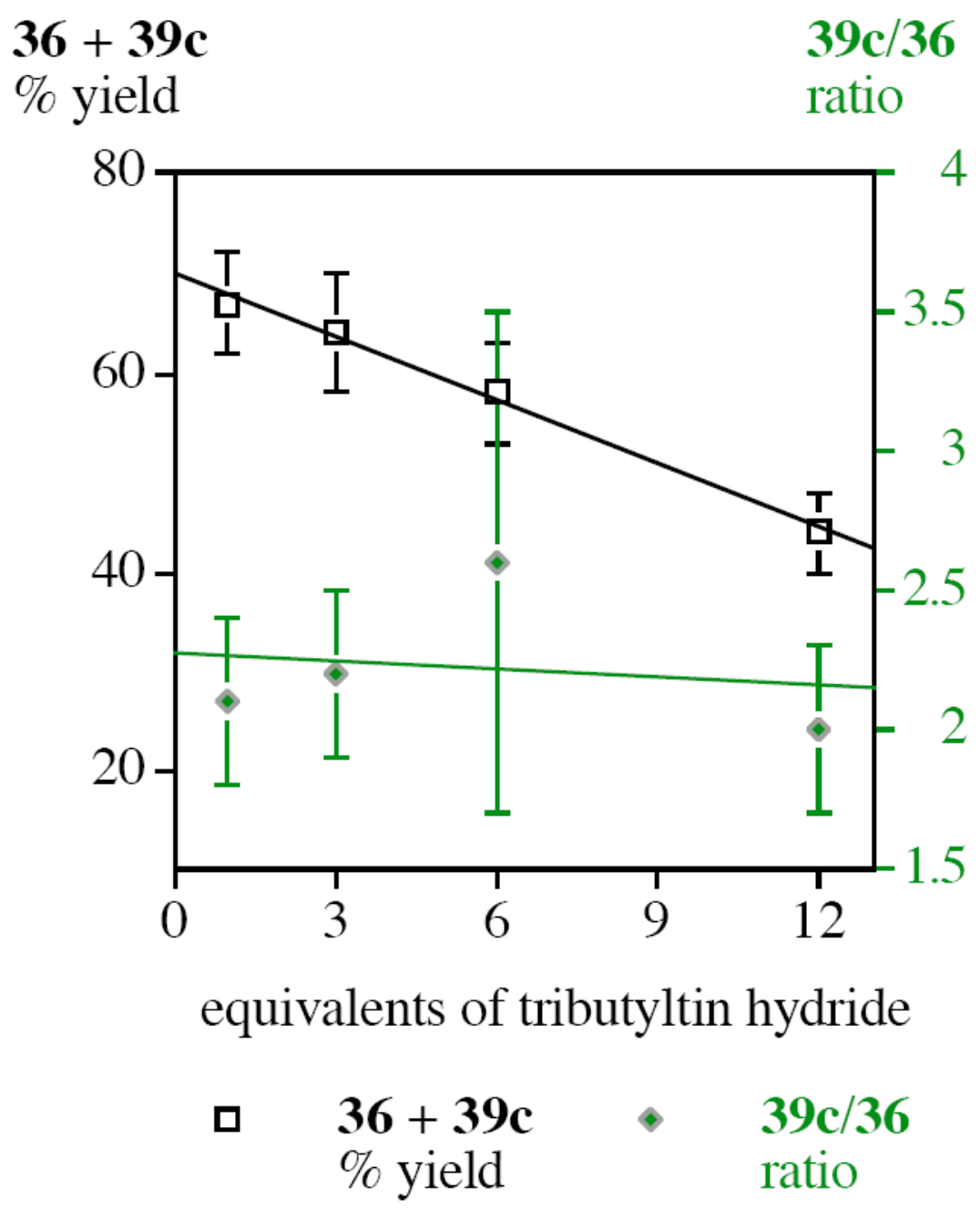

Figure 4.

Yield and ratio of aromatic trapping product 39c/36 upon increasing $\left[\mathrm{Bu}_{3} \mathrm{SnH}\right]$. All data points result from averaging quadruplicate or pentuplicate measurements. 
$36+39 f$

$\%$ yield

90

90

8

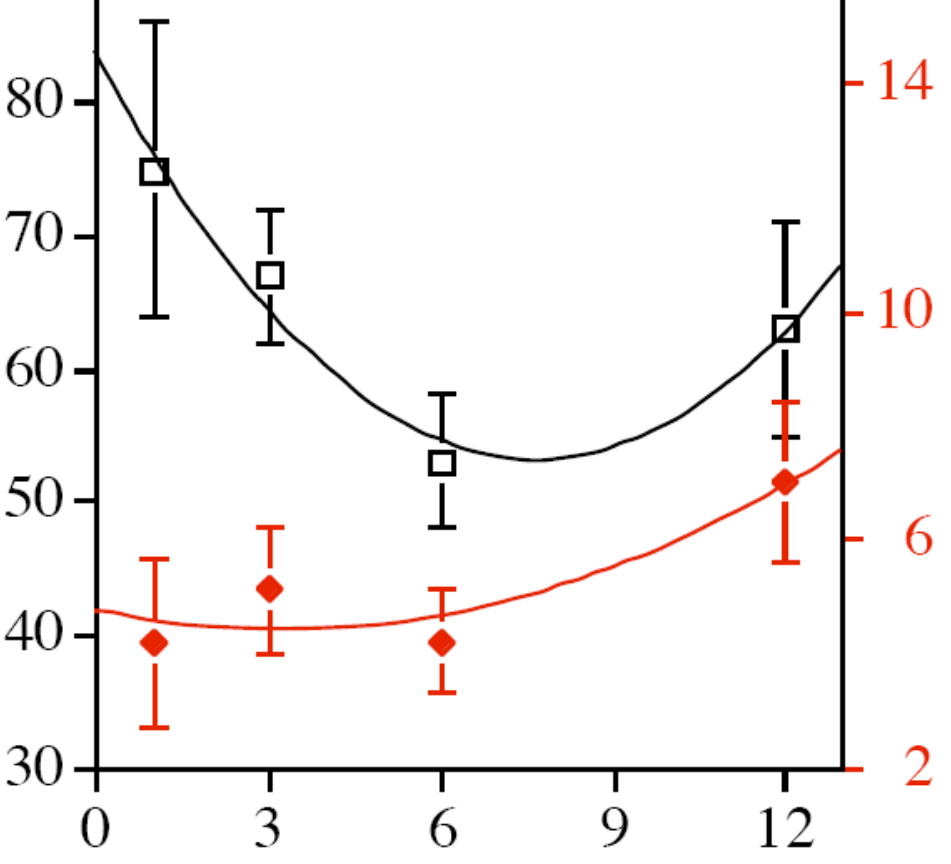

equivalents of tributyltin hydride 39f $/ 36$

ratio

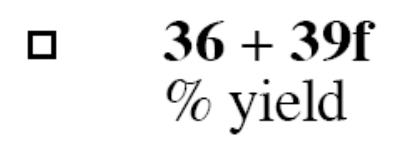

39f $/ 36$

ratio

Figure 5.

Yield and ratio of aromatic trapping product $\mathbf{3 9 f} / \mathbf{3 6}$ upon increasing $\left[\mathrm{Bu}_{3} \mathrm{SnH}\right]$. All data points result from averaging quadruplicate or pentuplicate measurements. 
Hypothesis 1 (Jebaratnam):

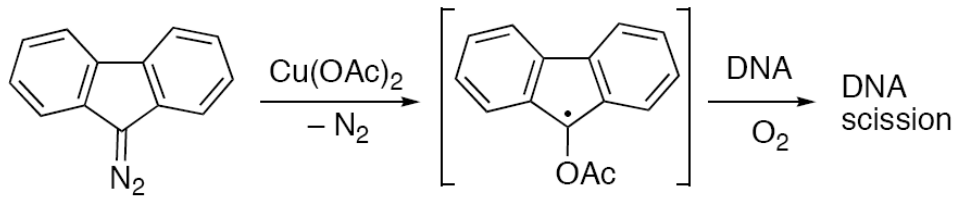

10

11

Hypothesis 2 (Dmitrienko):<smiles>[R20][R20]([H])([H])NC(C)Cc1cc(O)c2c3c(=O)c4cccc(O)c4c=3c(=O)c(=[W])c2c1</smiles><smiles></smiles>

$\beta$-naphthol

$\overrightarrow{\mathrm{Cs}_{2} \mathrm{CO}_{3}}$ $0^{\circ} \mathrm{C} \rightarrow \mathrm{rt}$<smiles>Cc1cc(O)c2c3c(c(O)c(N=N)c2c1)-c1c(O)cccc1C3=O</smiles><smiles>Nc1c(O)ccc2ccccc12</smiles><smiles>Cc1cc(O)c2c3c(c(O)cc2c1)-c1c(O)cccc1C3=O</smiles><smiles>Cc1cccc2c1-c1ccccc1C(=O)C2=N</smiles>

$13 \mathrm{IR}\left(\mathrm{N}_{2}\right)=2105 \mathrm{~cm}^{-1}$

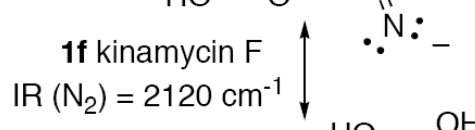<smiles></smiles>

1j kinamycin J IR $\left(\mathrm{N}_{2}\right)=2150 \mathrm{~cm}^{-1}$

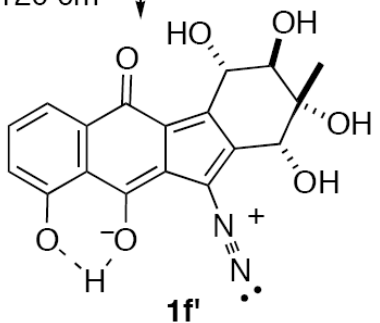

Scheme 1.

Previous mechanistic thinking on the role of the diazo function in reactions with model biological targets. 
generic $D$ ring of the kinamycins, lomaiviticins, or prekinamycin<smiles>C[C@]1([N+]=[N-])C2=C(CCCCCC2)C2=C1C(=O)c1c(O)ccc(O)c1C2=O</smiles>

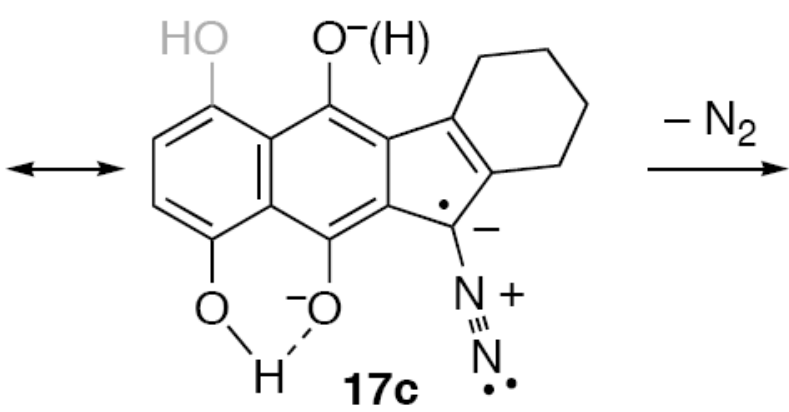<smiles>COc1c2c(c(O)c3c(O)ccc(O)c13)C1=C(CCCC1)C2=O</smiles>

18

Scheme 2.

Proposal for the generation of a $\mathrm{C}(11) \mathrm{sp}^{2}$ radical from diazoparaquinones via 1-electron reduction. 
<smiles></smiles>

18

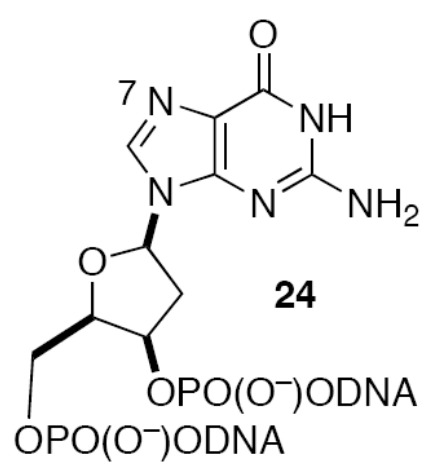

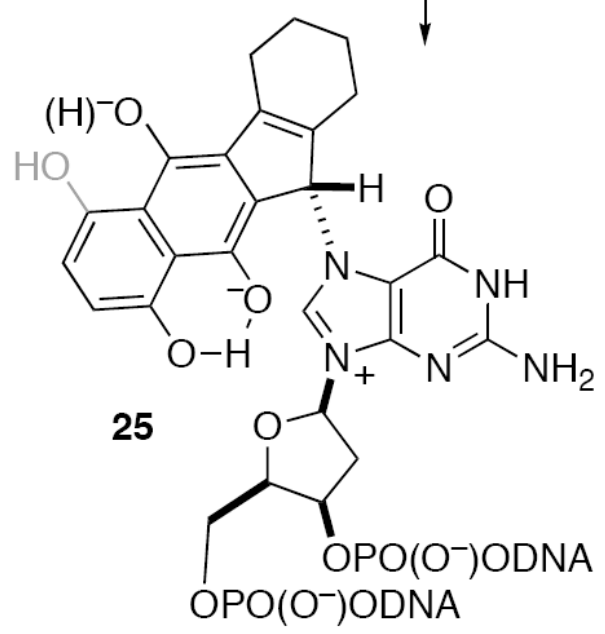<smiles>O=C1C=C2CC[CH+]CC2=C1C1=C([O-])c2c(O)ccc(O)c2C1=O</smiles>

22<smiles>[14CH2][14CH]([14CH2])[14CH3]</smiles><smiles>N#[N+][C@@H]1C2=C(CCCC2)c2c1c(O)c1c(O)ccc(O)c1c2[O-]</smiles>

23
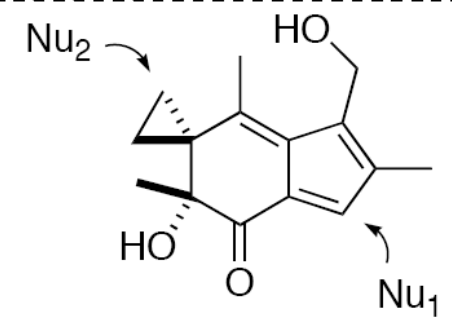

26 hydroxymethylacylfulvene<smiles>Cc1cc(O)c2c(c1)C(SCC(NC(C)C)C(=O)O)=C1C(=O)c3c(O)cccc3C(O)=C12</smiles>

27 seongomycin

Scheme 3.

Speculative pathways by which radical 18 might ultimately lead to DNA damage. 
<smiles>[R20]c1cc(C)cc2c(=N)c3c(=O)c4c(O)cccc4c(=O)c=3c12</smiles>

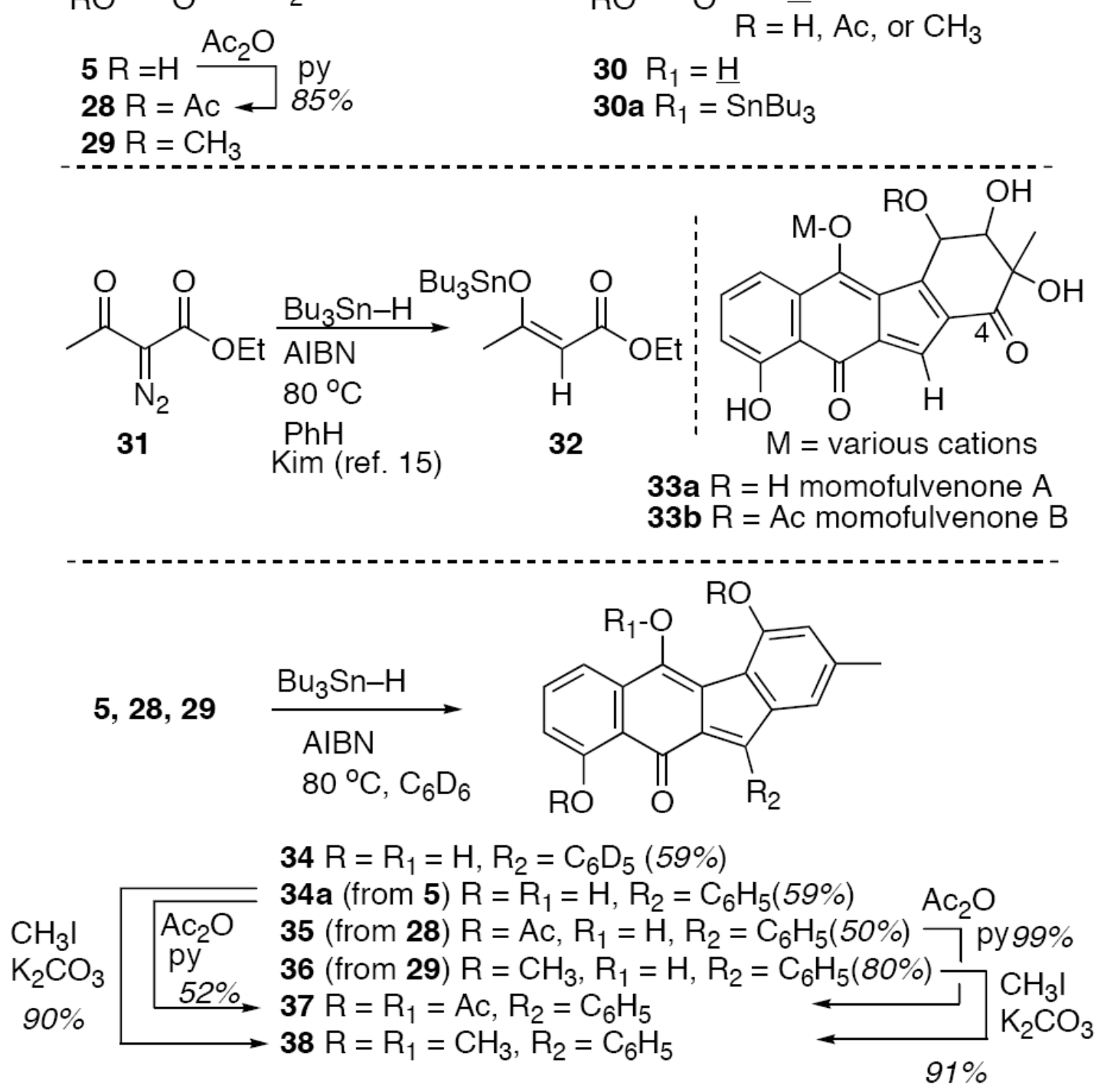

Scheme 4.

Preliminary experiments to probe the formal 1-electron reduction chemistry of prekinamycin and derivatives. 
<smiles>COc1cc(C)cc2c1-c1c(OC)cc(C)cc1C2=O</smiles>

29

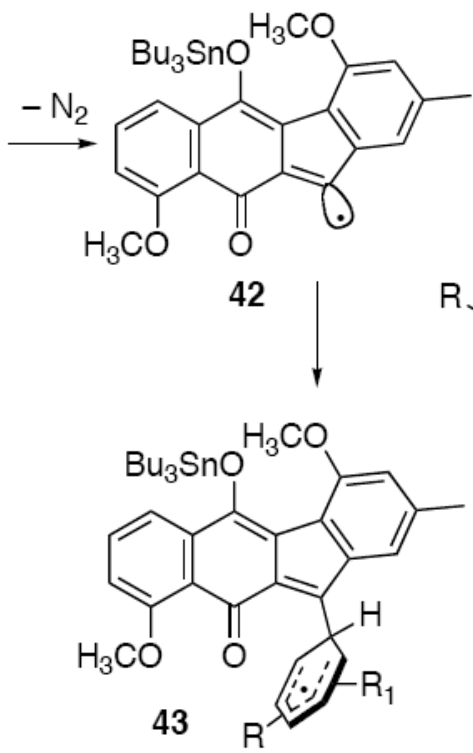

43

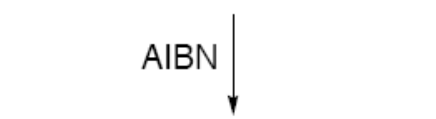<smiles>[R]c1cccc([R])c1</smiles>

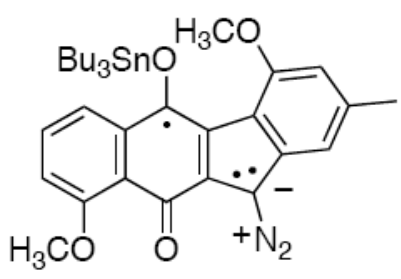

41

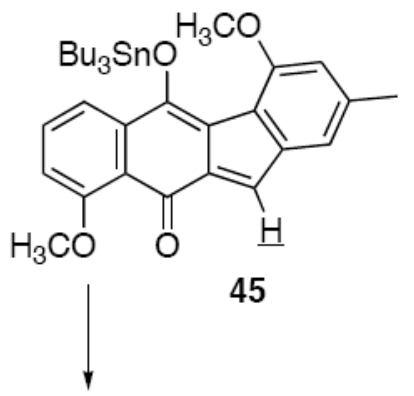

$\mathrm{Bu}_{3} \mathrm{Sn}-\underline{\mathrm{H}}$<smiles>[R]c1ccc([C@H]2c3c(c(O[Ga])c4c(OC)cccc4c3OC)-c3c(OC)cc(C)cc3[C@H]2c2cccc([R])c2)cc1</smiles>
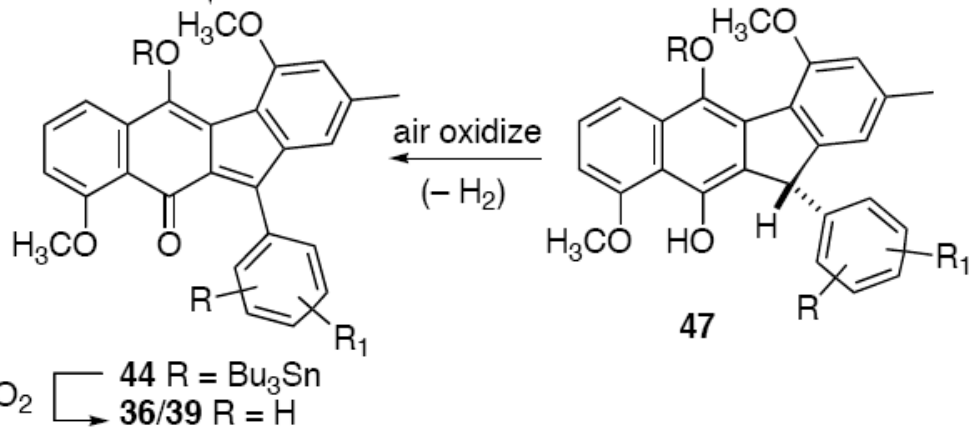

Scheme 5.

A mechanistic proposal for the formation of arene adducts 36/39 from diazoparaquinone 29 . 


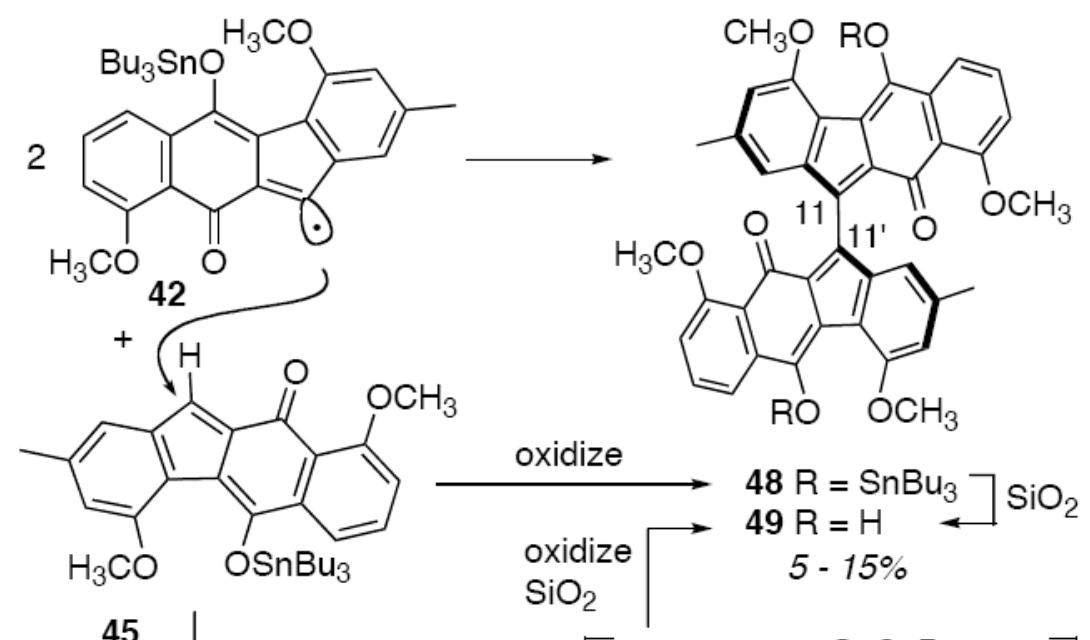

45
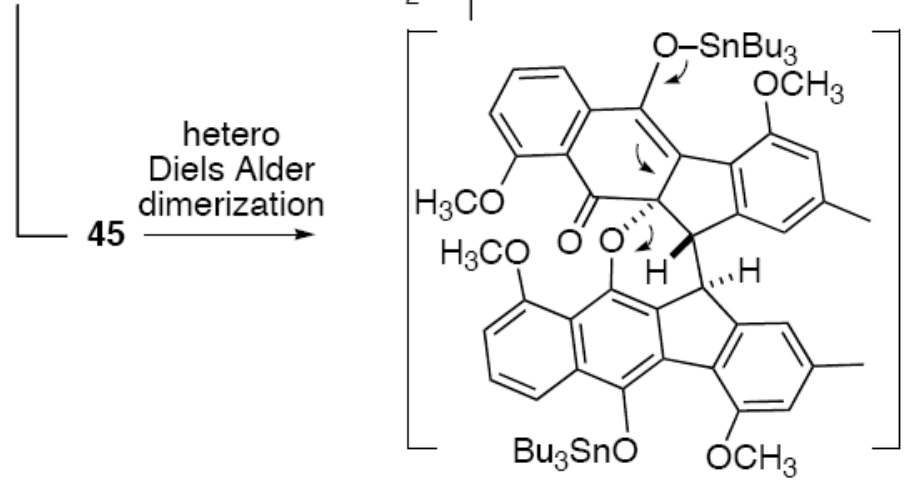

50

Scheme 6.

Plausible routes to the $\mathrm{C}(11)-\mathrm{C}\left(11^{\prime}\right)$ dimer 49. 


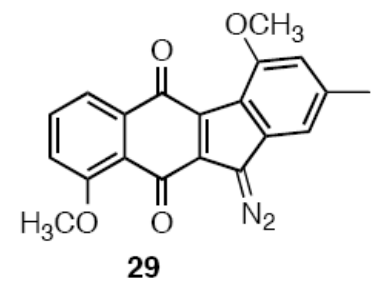

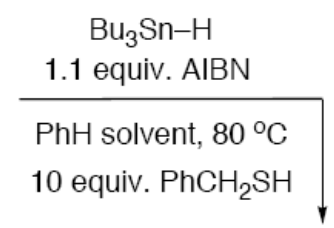<smiles></smiles><smiles>COc1cc(C)cc2c1C(O)=C1C(=O)c3c(OC)cccc3C3C=CC(=O)C3=C12</smiles><smiles>CCc1cccc([C@]2(SBr)c3cc(C)cc(OC)c3-c3c2c(O)c2cccc(OC)c2c3O)c1CCc1ccccc1</smiles><smiles>COc1cc(C)cc2c1C1=C(O[Ga]C)c3cccc(OC)c3C(=O)C1=C2</smiles>

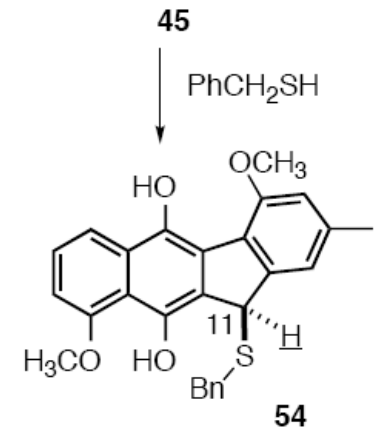

\begin{tabular}{ccccc}
$\begin{array}{c}\text { equiv. } \\
\mathrm{Bu}_{3} \mathrm{Sn}-\mathrm{H}\end{array}$ & $\begin{array}{c}\text { total } \\
\text { yield }\end{array}$ & $\mathbf{5 3}(\%)$ & $\mathbf{3 6}(\%)$ & $\mathbf{5 4}(\%)$ \\
\hline 1.1 & $83 \%$ & $22 \%$ & $15 \%$ & $46 \%$ \\
12 & $90 \%$ & $23 \%$ & $10 \%$ & $57 \%$ \\
& & & \\
& & & & \\
& & & & \\
& & &
\end{tabular}

Scheme 7.

Thiol adduct formation in the reductive activation of diazoparaquinone 29 . 


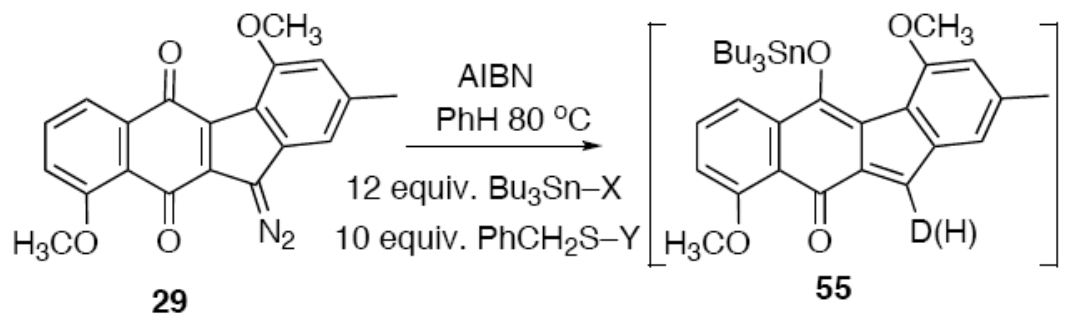

29

\begin{tabular}{cccc}
$\mathrm{X}$ & $\mathrm{Y}$ & $\% \mathbf{5 6}$ & $\% \mathrm{D}$ \\
\hline $\mathrm{D}$ & $\mathrm{H}$ & 40 & 27 \\
$\mathrm{H}$ & $\mathrm{D}$ & 33 & 46 \\
$\mathrm{D}$ & $\mathrm{D}$ & 46 & 76
\end{tabular}

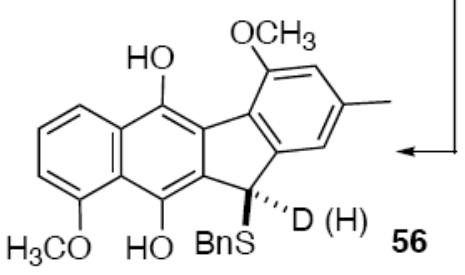

1) $\mathrm{PhCH}_{2} \mathrm{~S}-\mathrm{Y}$

2) $\mathrm{SiO}_{2}$

Scheme 8.

Deuterium labeling experiments with diazoparaquinone 29 and $\mathrm{Bu}_{3} \mathrm{SnD}$ and/or $\mathrm{PhCH}_{2} \mathrm{SD}$. 


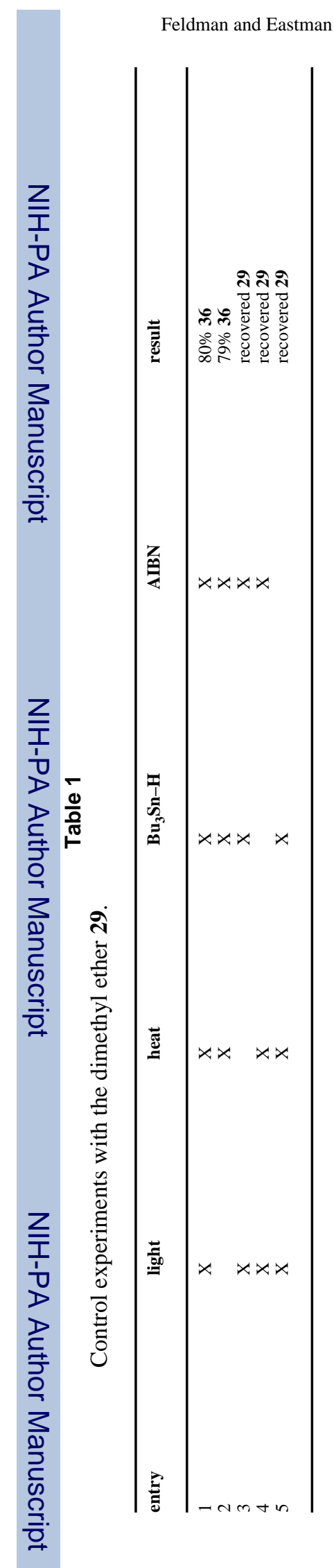

Page 32 

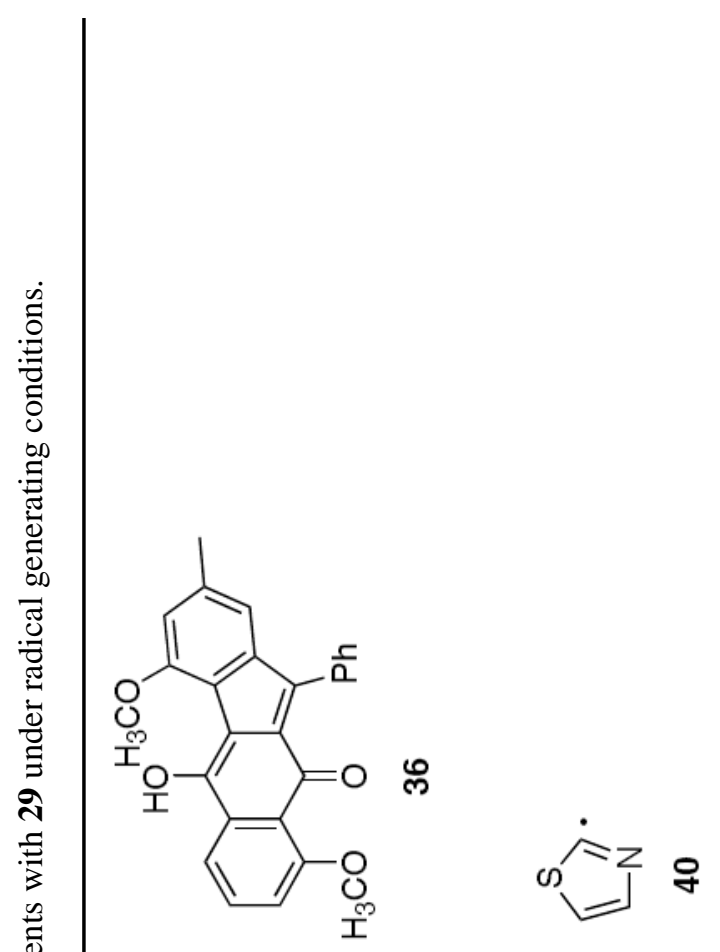

そ

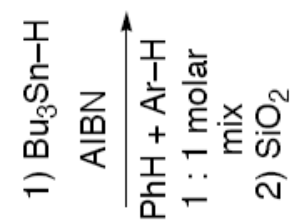<smiles>COc1cccc2c(=O)c3c(=O)c4c(O)cc(C)cc4c=3c(=O)c12</smiles>

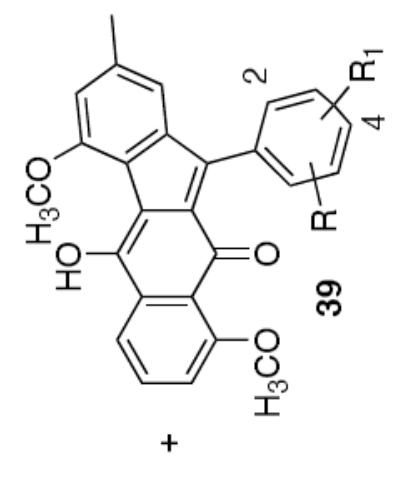
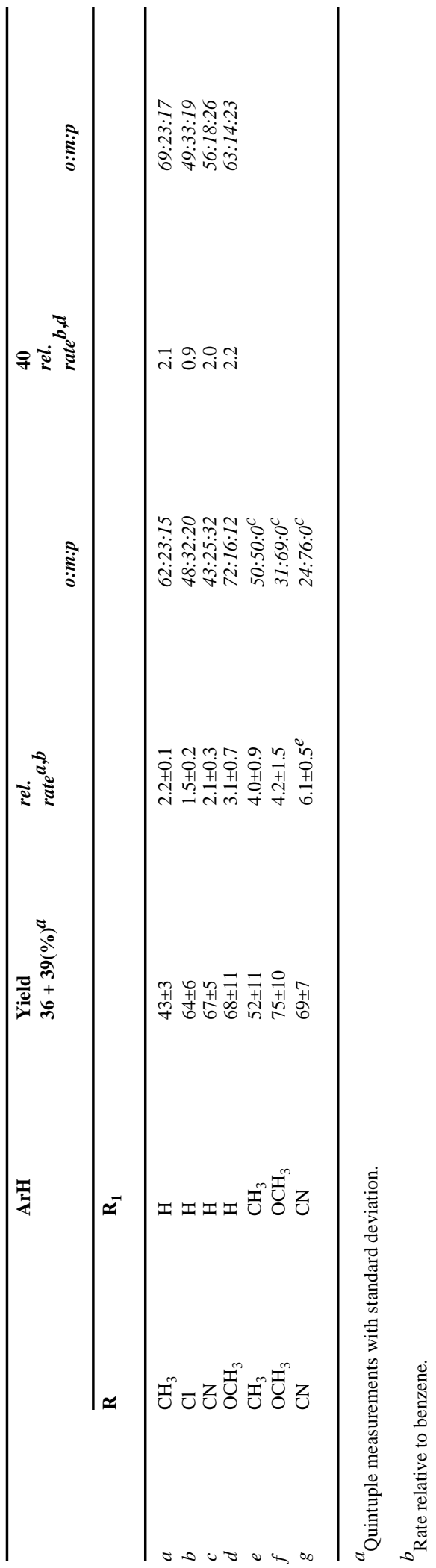

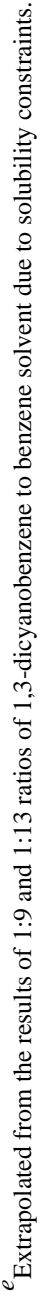

